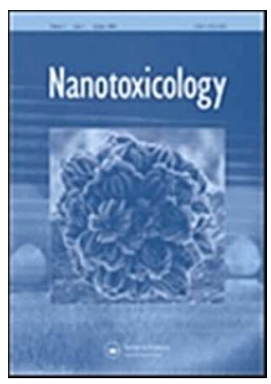

\title{
Lysine-based surfactants in nanovesicle formulations: the role of cationic charge position and hydrophobicity in in vitro cytotoxicity and intracellular delivery
}

\begin{tabular}{|r|l|}
\hline Journal: & Nanotoxicology \\
\hline Manuscript ID: & Draft \\
\hline Manuscript Type: & Original Article \\
\hline Domplete List of Authors: & $\begin{array}{l}\text { Nogueira, Daniele; Universitat de Barcelona, } \\
\text { Moran, Maria del Carmen; Universitat de Barcelona, } \\
\text { Mitjans, Montserrat; Universitat de Barcelona, } \\
\text { Perez, Lourdes; IQAC, CSIC, } \\
\text { Ramos, David; Parc Cientific de Barcelona, } \\
\text { de Lapuente, Joaquin; Parc Cientific de Barcelona, } \\
\text { Vinardell, Pilar; Universitat de Barcelona, }\end{array}$ \\
\hline Keywords: & Drug Delivery, Nanotoxicology \\
\hline & \multicolumn{2}{|l}{} \\
\hline
\end{tabular}

\section{SCHOLARONE"}

Manuscripts 


\title{
Lysine-based surfactants in nanovesicle formulations: the role of cationic charge position and hydrophobicity in in vitro cytotoxicity and intracellular delivery
}

\author{
Daniele Rubert Nogueira ${ }^{1}$, M. Carmen Morán ${ }^{1,4}$, Montserrat Mitjans ${ }^{1,4}$, Lourdes Pérez ${ }^{2}$, David \\ Ramos $^{3}$, Joaquín de Lapuente ${ }^{3}$, M. Pilar Vinardell ${ }^{1,4, *}$ \\ ${ }^{1}$ Departament de Fisiologia, Facultat de Farmàcia, Universitat de Barcelona, Av. Joan XXIII \\ $s / n, 08028$, Barcelona, Spain \\ ${ }^{2}$ Departamento de Tecnología Química y de Tensioactivos, IQAC, CSIC, C/Jordi Girona 18-26, \\ 08034, Barcelona, Spain \\ ${ }^{3}$ Unidad de Toxicología y Ecotoxicología del Parc Cientific de Barcelona, Baldiri Reixac 4, \\ 08028, Barcelona, Spain \\ ${ }^{4}$ Unidad Asociada al CSIC, Spain \\ * Corresponding author \\ Tel: (+34) 934024505; Fax: (+34) 934035901 \\ E-mail: mpvinardellmh@ub.edu (M. Pilar Vinardell)
}

Keywords: nanotoxicity, $\mathrm{pH}$-sensitivity, drug delivery, cell culture, cell internalization. 


\begin{abstract}
Understanding nanomaterial interactions within cells is of increasing importance for assessing their toxicity and cellular transport. Here, we developed nanovesicles containing bioactive cationic lysine-based amphiphiles, and assessed whether these cationic compounds increase the likelihood of intracellular delivery and modulate toxicity. We found different cytotoxic responses among the formulations, depending on surfactant, cell line and endpoint assayed. The induction of mitochondrial dysfunction, oxidative stress and apoptosis were the general mechanisms underlying cytotoxicity. Fluorescence microscopy analysis demonstrated that nanovesicles were internalized by HeLa cells, and evidenced that their ability to release endocytosed materials into cell cytoplasm depends on the structural parameters of amphiphiles. The cationic charge position and hydrophobicity of surfactants determine the nanovesicle interactions within the cell and, thus, the resulting toxicity and intracellular behavior after cell uptake of the nanomaterial. The insights into some toxicity mechanisms of these new nanomaterials contribute to reducing the uncertainty surrounding their potential health hazards.
\end{abstract}




\section{Introduction}

Nanomaterials (NMs) are classically defined as substances that have one or more external dimensions on a sub-100 nm scale (Horie et al. 2012), although some authors classify them as all submicronic particles up to $200 \mathrm{~nm}$ (Paillard et al. 2010). At this size, NMs might be easily taken up by cells and interact in a unique fashion with biological systems, which opens up a wide range of interesting applications, including the development of drug and gene delivery systems (Robbens et al. 2010).

Lipid bilayer vesicles are the most prominent colloidal drug carriers, as they can transport drug molecules into the interior of the vesicle, solubilize drugs in the lipid bilayer, or adsorb drugs at the lipid-water interface (Cevc 2012; Liang and Chou 2009). To date, all pharmaceutically used lipid-based vesicles consist of phospholipids (mainly phosphatidylcholine) supplemented with cholesterol, due to the widespread, but not always justified, belief that this is a prerequisite for bilayer stability (Cevc 2012). The inclusion of additives in lipid-based vesicles might help to fulfill the unmet, or partially unmet, goals of these lipid delivery systems. For example, it may increase absorption, improve controlled release and target specificity (Bombelli et al. 2005), and facilitate intracellular delivery (Chen et al. 2004). Additives with non-viral properties, including surfactants, lipids, peptides and polymers, are being intensively studied (Chen et al. 2004; Liang and Chou 2009; Zhang et al. 2004). In this line of research, current directions and the reported advantageous features of the amino acidbased surfactants (Colomer et al. 2012; Nogueira et al. 2011a, 2012a; Pérez et al. 2009) make them a promising group of novel additives for this kind of drug carriers (Lundberg et al. 2011; Morán et al. 2010). The amino acid-based amphiphiles have a structural relationship with endogenous substances and their synthesis can largely be based on non-toxic building blocks, which potentiallly gives them good biocompatibility (Infante et al. 2010; Lundberg et al. 2011). 
Advances in strategies for treating a wide variety of diseases require the efficient delivery of active compounds into the cytosol of target cells (Hu et al. 2007). One common strategy for the intracellular delivery of encapsulated and/or intercalated material via lipid-based vesicles exploits intracellular $\mathrm{pH}$ gradients (Pollock et al. 2010). Therefore, an approach for cytosolic drug delivery is the development of $\mathrm{pH}$-sensitive lipid-based vesicles (Di Marzio et al. 2011; Simões et al. 2004), which contain pH-responsive components that are stable at physiological $\mathrm{pH}$ (7.4), but undergo destabilization under the acidic environments encountered during endocytosis. Consequently, their contents are released at intracellular level (Di Marzio et al. 2011). In our previous studies on amino acid-based surfactants, we showed that new cationic lysine-based amphiphiles (hydrochloride salts of $\mathrm{N}^{\varepsilon}$-acyl lysine methyl ester) have $\mathrm{pH}$ responsive membrane lytic activity (Nogueira et al. 2012a, 2012b). Thus, they are highly suitable for incorporation in carriers designed for intracellular drug delivery. The potential advantages of this class of cationic lysine-based surfactants as additives in devices designed for drug delivery motivated us to develop new nanovesicles (NVs) containing these amphiphiles as surface modification agents. We study whether these cationic compounds increase the likelihood of intracellular delivery, establish the physicochemical properties of such carriers and modulate their cytotoxic potential. In line with the likely advantages of cationic delivery systems, cationic lipid-based carriers have attracted considerable interest because of their use as effective drug and gene delivery systems (Dakwar et al. 2012; Lundberg et al. 2011; Ramezani et al. 2009).

In the present study, we assessed the impact of including three cationic lysine-based surfactants in lipid-based NVs. These amphiphiles differed in the cationic charge position and the alkyl chain length. Consequently, we investigated specifically whether these structural parameter changes play a key role in the general outcome of the NVs. The potential topical application of these formulations were explored in our previous study, in which we showed no phototoxicity, slight inflammatory potential, and acceptable toxic responses in representative 
skin cell lines (Nogueira et al. 2013). Here, we tested the feasibility of these NVs as efficient drug delivery devices for intravenous administration and intracellular delivery of biomolecules. With this objective, we focused on the performance of a broad in vitro nanotoxicity study of these new nanocarriers, together with an assessment of their uptake by cells and ability to deliver contents intracellularly, using nile red and calcein as fluorescent markers, respectively. We aimed to increase understanding of the various steps in nanocarrier cytotoxicity, as little is known about the mechanisms underlying this effect. The potential toxic mechanisms of the increasing number of nanocarriers have not been explained sufficiently. Additionally, relationships between the cytotoxic responses and NM composition are not well understood. Thus, the search for reliable conditions to assess NM safety is an emerging field that poses many interesting challenges (Marquis et al. 2009).

\section{Materials and Methods}

\section{Chemicals and reagents}

Acridine orange (AO), ethidium bromide (EB), propidium iodide, ribonuclease A (RNAse A), nile red (NR), calcein, 2,5-diphenyl-3,-(4,5-dimethyl-2-thiazolyl) tetrazolium bromide (MTT), neutral red (NR) dye, 4,6-diamidino-2-phenylindole dihydrochloride (DAPI), 1,2-dimyristoylsn-glycero-3-phosphocholine (DMPC), cholesterol (CHOL) and dimethylsulphoxide (DMSO) were obtained from Sigma-Aldrich (St. Louis, MO, USA). Dulbecco's Modified Eagle's Medium (DMEM), fetal bovine serum (FBS), phosphate buffered saline (PBS), L-glutamine solution $(200 \mathrm{mM})$, trypsin-EDTA solution $(170,000 \mathrm{U} / 1$ trypsin and $0.2 \mathrm{~g} / \mathrm{l}$ EDTA) and penicillin-streptomycin solution $(10,000 \mathrm{U} / \mathrm{ml}$ penicillin and $10 \mathrm{mg} / \mathrm{ml}$ streptomycin) were purchased from Lonza (Verviers, Belgium). The $75 \mathrm{~cm}^{2}$ flasks and 96-well plates were obtained from TPP (Trasadingen, Switzerland). All other reagents were of analytical grade.

\section{Surfactants included in the nanovesicular systems}


Three new biocompatible amino acid-based surfactants with one lysine as the cationic polar head (one cationic charge) and one alkyl chain were used as surface modification agents to prepare the cationic nanovesicular systems reported in this study. The surfactants were: $\mathrm{N}^{\varepsilon}$ myristoyl lysine methyl ester (MKM) with one alkyl chain of 14 carbon atoms and one positive charge on the $\alpha$-amino group of the lysine; $\mathrm{N}^{\varepsilon}$-palmitoyl lysine methyl ester (PKM) with one alkyl chain of 16 carbon atoms and one positive charge on the $\alpha$-amino group of the lysine; and $\mathrm{N}^{\alpha}$-myristoyl lysine methyl ester (MLM) with one alkyl chain of 14 carbon atoms and one positive charge on the $\varepsilon$-amino group of the lysine. MKM and PKM have a hydrophobic chain attached to the $\varepsilon$-amino group of the lysine, while MLM has its hydrophobic chain attached to the $\alpha$-amino group. These lysine-based surfactants were synthesized in our laboratory, as described elsewhere (Colomer et al. 2012; Pérez et al. 2009).

\section{Preparation of cationic nanovesicular formulations}

The mixed cationic NVs were prepared by the film hydration method, as previously described (Nogueira et al. 2013). DMPC and cholesterol (CHOL) were selected as basic lipid membrane components and were mixed with MKM, PKM or MLM in the designed molar ratios, as described in the Table 1 . The total final concentration of each mixed cationic NV was fixed at 2 mM. NV dispersions were purified by filtration using Vivaspin 2 centrifugal concentrator (PES membrane, 3,000 MWCO, Sartorius Stedim Biotech, Goettingen, Germany). The filtered substance was used to determine the extent of incorporation of the cationic surfactants into the vesicles and the amount of unincorporated surfactant was assessed by high-performance liquid chromatography, following the previously described analytical method (Pérez et al. 2009).

NVs physically encapsulating Nile red as a fluorescent marker (NR-NVs) were also prepared. The formulation DMPC:MKM $(80: 20, \mathrm{w} / \mathrm{w})$ was used as a model in this study. Nile red $1 \mathrm{~mol} \%$ (of the final concentration of the formulation), was dissolved with the phospholipid and the surfactant prior to obtaining the film. Then, the nanovesicle preparation followed the 
same procedure as that described above. The NR-NVs were further purified to eliminate the non-encapsulated dye by ultracentrifugation with multiple washing with ultrapure water.

\section{Nanovesicle characterization}

The mean hydrodynamic diameter and the polydispersity index (PDI) of the cationic NVs were determined by dynamic light scattering (DLS) using a Malvern Zetasizer ZS (Malvern Instruments, Malvern, UK). Before measurement, the NVs were appropriately diluted in ultrapure water or cell culture medium with $5 \%(\mathrm{v} / \mathrm{v}) \mathrm{FBS}$. Readings were taken at $25^{\circ} \mathrm{C}$ immediately after preparation $(\mathrm{t}=0 \mathrm{~h})$ and after a $24 \mathrm{~h}$ incubation at $37^{\circ} \mathrm{C}(\mathrm{t}=24 \mathrm{~h})$. Each measurement was performed using at least three sets of a minimum of ten runs. The zeta potential (ZP) values of the NVs were assessed by determining electrophoretic mobility with the Malvern Zetasizer ZS equipment. The measurements were also performed in ultrapure water and cell culture medium with $5 \%(\mathrm{v} / \mathrm{v}) \operatorname{FBS}\left(\mathrm{t}=0 \mathrm{~h}, 25^{\circ} \mathrm{C}\right)$, using at least three sets of a minimum of 20 runs. These experiments were performed as previously described (Nogueira et al. 2013), but additional analyses were carried out to assess the NV stability in ultrapure water after $24 \mathrm{~h}$ and 1 week incubation at $37^{\circ} \mathrm{C}$ and $4^{\circ} \mathrm{C}$, respectively.

The morphology and size of the NVs were analyzed by transmission electron microscopy (TEM), as previously described (Nogueira et al. 2013). The images were obtained with a Jeol JEM-1010 electron microscope (Jeol Ltd., Tokyo, Japan) operating at an acceleration voltage of $80 \mathrm{kV}$.

\section{Cell cultures}

The 3 T3 (murine Swiss albino fibroblasts) and the HeLa (human epithelial cervical cancer) cell lines were grown in DMEM medium (4.5 g/l glucose) supplemented by $10 \%(\mathrm{v} / \mathrm{v}) \mathrm{FBS}, 2 \mathrm{mM}$ L-glutamine, $100 \mathrm{U} / \mathrm{ml}$ penicillin and $100 \mu \mathrm{g} / \mathrm{ml}$ streptomycin at $37^{\circ} \mathrm{C}, 5 \% \mathrm{CO}_{2}$. These cells were routinely cultured in $75 \mathrm{~cm}^{2}$ culture flasks and were trypsinized using trypsin-EDTA when 
the cells reached approximately $80 \%$ confluence. The cell lines were obtained from Eucellbank (Universitat de Barcelona, Spain). We selected these cell lines as model systems because the use of cells from different species and with different embryonic origins is an important approach to understand the cell specific responses induced by NMs (Fröhlich et al. 2012).

\section{Cytotoxicity assays: MTT, NRU and LDH}

The $3 \mathrm{~T} 3\left(1 \times 10^{5}\right.$ cells $\left./ \mathrm{ml}\right)$ and HeLa $\left(5 \times 10^{4}\right.$ cells $\left./ \mathrm{ml}\right)$ cells were seeded into the 60 central wells of 96-well cell culture plates in $100 \mu 1$ of complete culture medium. Cells were incubated for $24 \mathrm{~h}$ under $5 \% \mathrm{CO}_{2}$ at $37^{\circ} \mathrm{C}$. The medium was then replaced with $100 \mu \mathrm{l}$ of fresh medium supplemented by 5\%(v/v) FBS containing the NV dispersions in the $0.5-100 \mu \mathrm{M}$ concentration range. The surfactants only and NVs without any surfactant (DMPC only and DMPC:CHOL 70:30) were also assessed in the same concentration range. Each concentration was tested in triplicate and control cells were exposed to the medium with $5 \%$ (v/v) FBS only. The cell lines were incubated for $24 \mathrm{~h}$ with each treatment.

The MTT assay is a measurement of cell metabolic activity in the mitochondria of viable cells and was performed as previously described (Nogueira et al. 2013). Cell viability was calculated as the percentage of tetrazolium salt reduction by viable cells in each sample and the values were normalized by the untreated cell control (cells with medium only).

The NRU assay determines the accumulation of NR dye in the lysosomes of cells and reflects the functionality of the lysosomes and plasma membrane (Fröhlich et al. 2012). The assay was performed following the previously described methodology (Nogueira et al. 2013). The effect of each treatment was calculated as the percentage of uptake of NR dye by lysosomes against the untreated cell control (cells with medium only).

LDH leakage was determined in the conditioned medium using a commercially available kit (Takara Bio Inc, Otsu, Japan), according to the instructions provided by the manufacturer. This assay is an indicator of plasma membrane integrity and quantifies cytotoxicity by 
measuring LDH released from dead or plasma membrane-damaged cells into the supernatant (Yang et al. 2009). Results are expressed as a percentage of the control, with $1 \%$ (v/v) Triton-X used as a positive control.

One of the possible limitations of the cytotoxicity study of NMs is their interference with the dyes used in the viability assays. Therefore, we determined whether the NVs interact with the viability assays using UV-visible absorbance measurements (Monteiro-Riviere et al. 2009, 2010). NVs at $100 \mu \mathrm{M}$ were suspended in DMEM medium (without FBS and phenol red) containing MTT $(0.5 \mathrm{mg} / \mathrm{ml})$ or NR $(50 \mu \mathrm{g} / \mathrm{ml})$ dyes, and the occurrence of dye interference was assessed following the procedure previously described (Nogueira et al. 2013).

\section{Apoptosis}

NV-induced apoptosis in 3T3 cells was quantified using acridine orange/ethidium bromide (AO/EB) double staining, according to standard procedure (Squier and Cohen 2001). Samples were examined under a fluorescence microscope. Briefly, cells were seeded $\left(1 \times 10^{5}\right.$ cells $\left./ \mathrm{ml}\right)$ in 24-well plates and treated with $\mathrm{IC}_{50}$ concentration (calculated by MTT assay). After $24 \mathrm{~h}$ incubation, the cells were trypsinized and centrifuged at $1200 \mathrm{rpm}$ for $5 \mathrm{~min}$. Then, the fluorescent dyes $\mathrm{AO}(0.5 \mu \mathrm{g} / \mathrm{ml})$ and $\mathrm{BE}(10 \mu \mathrm{g} / \mathrm{ml})$ were added to the cellular pellet. The freshly stained cell suspension was dropped on a glass slide and covered by a cover slip. Slides were observed under a fluorescent microscope (Olympus BX41 microscope equipped with a UV-mercury lamp, 100W Ushio Olympus, and a filter set type MNIBA3 470-495 nm excitation and $505 \mathrm{~nm}$ dichromatic mirror) and the percentage of viable, apoptotic, late apoptotic and necrotic cells was determined in at least 100 cells.

\section{Cell cycle analysis by flow cytometry}

The 3 T3 fibroblasts were cultured in $60 \mathrm{~mm}$ petridishes for $24 \mathrm{~h}$ at a density of $1 \times 10^{5}$ cells $/ \mathrm{ml}$ and then treated with $\mathrm{IC}_{20}$ and $\mathrm{IC}_{50}$ concentrations of each $\mathrm{NV}$ formulation. After $24 \mathrm{~h}$ treatment, 
the cells were harvested by trypsinization, washed in cold PBS, fixed in ice-cold $70 \%$ ethanol and kept at $-20^{\circ} \mathrm{C}$. Fixed cells were centrifuged, resuspended in DNA extraction buffer $(0.2 \mathrm{M}$ $\mathrm{Na}_{2} \mathrm{PO}_{4}$ and $0.1 \mathrm{M}$ citric acid, $\mathrm{pH} 7.8$ ) and incubated for $30 \mathrm{~min}$ at $37^{\circ} \mathrm{C}$. Then, the cells were centrifuged and stained with staining solution $(20 \mu \mathrm{g} / \mathrm{ml}$ propidium iodide, $200 \mu \mathrm{g} / \mathrm{ml}$ RNAse A and Triton X-100 in PBS). The samples were kept in dark conditions for $1 \mathrm{~h}$ and measured with the Beckman Coulter ADC Epics XL flow cytometer (Beckman Coulter, FL, USA). The amount of propidium iodide intercalating to DNA was used as the parameter to determine the cell cycle distribution phases. Aggregates were excluded gating single cells by their area vs. peak fluorescence signal. DNA analysis on single fluorescence histograms was done using Multicycle software (Phoenix Flow Systems, CA, USA).

\section{Genotoxicity}

DNA damage in the form of unrepaired single- and double-strand DNA breaks was detected using an alkaline single cell gel electrophoresis/comet assay, according to the method described by Singh et al. (1988), with some modifications by Di Guglielmo et al. (2012). The 3T3 cells were treated with the $\mathrm{IC}_{10}, \mathrm{IC}_{20}$ and $\mathrm{IC}_{30}$ concentrations (calculated by MTT assay) of each NV formulation. After $24 \mathrm{~h}$ incubation, the cells from 2 wells of each treatment were trypsinized and transferred to eppendorfs. Slides containing the samples were prepared. The cells were lysated and then incubated in alkaline electrophoresis buffer for DNA unwinding and conversion of alkali-labile sites to single-strand breaks. Electrophoresis was performed in the same buffer for 30 minutes at $25 \mathrm{~V}$ and $300 \mathrm{~mA}$. After that, $20 \mu \mathrm{L}$ of $5 \mu \mathrm{g} / \mathrm{ml}$ DAPI solution was added to each slide for the fluorescence microscopy analysis. The migration of nuclear DNA from the cells was measured using the COMET ASSAY IV ${ }^{\circledR}$ Program (Perspective Instruments) for 50 randomly selected cell images, and the mean percentage of DNA in the tail (\% Tail DNA) was calculated in each trial. Methyl methanesulfonate (MMS) at a concentration of $400 \mu \mathrm{M}$ was used as the positive control. 


\section{Oxidative damage}

Oxidative stress can be determined by biomarker stress products from lipid peroxidation (Marquis et al. 2009). We employed the reaction of malondialdehyde (MDA) with thiobarbituric acid (TBA) to indicate the oxidative damage caused by NVs. MDA is the end product of the peroxidation of polyunsaturated fatty acids, and has been extensively used as an index for lipid peroxidation. The $3 \mathrm{~T} 3$ fibroblasts were cultured in $60 \mathrm{~mm}$ petri dishes for $24 \mathrm{~h}$ at a density of 1 x $10^{5}$ cells $/ \mathrm{ml}$ and then treated with $\mathrm{IC}_{50}$ concentrations of each $\mathrm{NV}$ formulation. After $24 \mathrm{~h}$ treatment, the cells were trypsinized, centrifuged and resuspended in PBS. For the lipid extraction, cells were incubated with 3.2\% SDS and 30\% acetic acid, and $0.8 \%$ TBA was added. The reaction was carried out at $95^{\circ} \mathrm{C}$ for $1 \mathrm{~h}$ and the absorbance was then determined at $532 \mathrm{~nm}$ using a microplate reader. The MDA concentration in each sample was obtained from an MDA calibration curve $(0-15 \mathrm{nM} / \mathrm{ml})$. The values were normalized against the total cell protein content and the results expressed as $\mathrm{nM} \mathrm{MDA} / \mathrm{mg}$ protein. The protein content of the cell lysate was determined by a commercial kit (Bio-Rad, CA, USA) based on the Bradford dye-binding procedure (Bradford 1976). Hydrogen peroxide $\left(\mathrm{H}_{2} \mathrm{O}_{2}\right)$ at a concentration of $100 \mu \mathrm{M}$ was included in the assay as a positive control.

\section{Blood compatibility studies}

\section{Hemolysis and agglutination assays}

Erythrocytes were isolated from rat blood, which was obtained from anesthetized animals by cardiac puncture and drawn into tubes containing EDTA. The procedure was approved by the institutional ethics committee on animal experimentation. The hemolysis assay was performed following the previously described procedure (Nogueira et al. 2011a). Aliquots of 25- $\mu$ l of erythrocyte suspension were exposed to NV concentrations of 20, 100 and $200 \mu \mathrm{M}$, and dissolved in PBS buffer in a total volume of $1 \mathrm{ml}$. Two controls were prepared by resuspending erythrocyte suspension either in buffer alone (negative control) or in distilled water (positive 
control). The samples were incubated at room temperature for 10 minutes or $1 \mathrm{~h}$ and then centrifuged at 10,000 rpm for $5 \mathrm{~min}$. Absorbance of the hemoglobin release in supernatants was measured at $540 \mathrm{~nm}$ using a Shimadzu UV-160A spectrophotometer (Shimadzu, Kyoto, Japan) and the percentages of hemolysis were determined by comparison with the positive control samples completely hemolyzed with distilled water. For the erythrocyte agglutination studies, 10 $\mu \mathrm{l}$ of each sample that had been subjected to a hemolysis assay $(100 \mu \mathrm{M}$ for $1 \mathrm{~h})$ were placed on a glass slide, covered by a cover slip and analyzed by a phase contrast microscope (Olympus BX41, Olympus, Japan).

\section{Human plasma protein adsorption by SDS-PAGE and total protein assay}

Blood was drawn from the authors by venipuncture into tubes containing EDTA. It was then centrifuged at $3000 \mathrm{rpm}$ to obtain fresh plasma. NVs $(200 \mu \mathrm{M})$ were suspended in plasma diluted with PBS to $10 \%$ of normal strength and incubated for $1 \mathrm{~h}$ at $37^{\circ} \mathrm{C}$ with constant shaking. The NVs were separated from the plasma by multiple cycles of ultracentrifugation and washing steps with PBS. Firstly, an aliquot of the supernatant of each sample was taken and mixed with electrophoresis sample buffer. Then, the proteins adsorbed to the NVs were desorbed by sonication in electrophoresis sample buffer for $20 \mathrm{~min}$. Both samples were incubated at $95^{\circ} \mathrm{C}$ for 5 min. Thereafter, samples were applied onto pre-cast polyacrylamide gel $(7.5 \%$ resolving gel and a 5\% stacking gel). Electrophoresis was carried out for $10 \mathrm{~min}$ at $60 \mathrm{~V}$ followed by $35 \mathrm{~min}$ at 200 V. Protein bands were viewed by staining with Coomassie Brilliant Blue R-250 for an hour under gentle shaking. Samples were then destained with a mixture of $7.5 \%$ methanol and $10 \%$ acetic acid. The molecular weight of the membrane proteins was estimated from the molecular size marker (Bio-Rad Precision Plus Unstained Standard), and ranged from 10 to 250 $\mathrm{kDa}$. Finally, portions of the supernatant and the fluid desorbed from NVs were also taken for total protein assay using the Bio-Rad kit (Bio-Rad, CA, USA), which is based on the Bradford 
dye-binding procedure (Bradford 1976), using bovine serum albumin (BSA) as a protein standard.

\section{Cell uptake studies}

\section{Intracellular localization of Nile red-labeled nanovesicles}

To study the cell uptake, DMPC:MKM (80:20, w/w) NVs that physically encapsulated Nile red (NR-NVs) were prepared. HeLa cells were plated in 24 -well plates at a density of $5 \times 10^{4}$ cells/ml on round cover glasses (Marlenfeld GmbH \& Co.KG, Lauda-Könlgshofen, Germany) and incubated overnight at $37^{\circ} \mathrm{C}$ under $5 \% \mathrm{CO}_{2}$. After that, the culture medium was replaced with fresh medium containing NR-NVs at a final concentration of $50 \mu \mathrm{M}(0.5 \mu \mathrm{M}$ of NR) and incubated for $2 \mathrm{~h}$ and $24 \mathrm{~h}$. Following incubation, the test samples were aspirated and the cells were washed three times with PBS and fixed with 4\% (v/v) formaldehyde in PBS (pH 7.4) for $15 \mathrm{~min}$ at room temperature. The individual cover glasses were then mounted on clean glass slides with Prolong® Gold antifade reagent (Invitrogen, OR, USA) for subsequent fluorescence microscopy analysis (Olympus BX41 microscope equipped with a UV-mercury lamp, 100W Ushio Olympus, and a filter set type MNIBA3 470-495 nm excitation and $505 \mathrm{~nm}$ dichromatic mirror). Images were digitized on a computer through a video camera (Olympus digital camera $\mathrm{XC50})$ using an image processor (Olympus cell^ ${ }^{\wedge}$ Image Acquisition Software). The images were then analyzed with ImageJ software (v. 1.46, National Institutes of Health, MD, USA) (Collins 2007; Rasband 1997) to calculate the mean fluorescence value of the cells, which corresponds to the cell internalization of NVs. For each condition, $\sim 20$ individual cells from different fields and images were analyzed and their total fluorescence intensity was quantified.

\section{Intracellular release of calcein}

Calcein (a membrane-impermeable fluorophore) was used as a tracer molecule to monitor the effect of the NVs on endosomes after cell internalization. HeLa cells were plated $\left(5 \times 10^{4}\right.$ 
cells $/ \mathrm{ml}$ ) in 24-well plates on round cover glasses (Marlenfeld GmbH \& Co.KG, LaudaKönlgshofen, Germany) and incubated overnight at $37^{\circ} \mathrm{C}$ under $5 \% \mathrm{CO}_{2}$. Then, calcein (1 $\mathrm{mg} / \mathrm{ml}$ ) was added to the cells with or without (control cells) $50 \mu \mathrm{M}$ of each NV formulation in DMEM medium without FBS and phenol red. After $1 \mathrm{~h}$ incubation at $37^{\circ} \mathrm{C}$, the cells were washed four times with PBS and incubated in complete medium for $3 \mathrm{~h}$ to allow intracellular trafficking. The cells were then washed four times with PBS and fixed with 4\% (v/v) formaldehyde in PBS (pH 7.4) for 15 min at room temperature. Each individual cover glasses was mounted on a clean glass slide with Prolong ${ }^{\circledR}$ Gold antifade reagent (Invitrogen, OR, USA) and analyzed on a Olympus BX41 fluorescence microscope equipped with a UV-mercury lamp (100W Ushio Olympus) and a filter set type MNIBA3 (470-495 nm excitation, 510-550 nm emission and $505 \mathrm{~nm}$ dichromatic mirror). Images were digitized on a computer through a video camera (Olympus digital camera XC50) using an image processor (Olympus cell ${ }^{\wedge} \mathrm{B}$ Image Acquisition Software). Thereafter, ImageJ software was used to calculate the average pixel intensity of calcein fluorescence within regions of interest (ROI) drawn on to collected images. Images of $\sim 20$ individual cells were analyzed for each treatment. This was done by drawing three ROI inside the cell (excluding any calcein-containing vesicles and, thus, representing the cytoplasm only) and the results were obtained in arbitrary fluorescence units (Jones et al. 2003).

\section{Statistical analysis}

The results of all in vitro assays are expressed as mean \pm standard error of the mean (SEM) of three independent experiments, which were performed using three replicate samples for each concentration tested. The cytotoxicity of each formulation was expressed in terms of its $\mathrm{IC}_{50}$ (the concentration causing 50\% death of the cell population), calculated from concentration-response curves. Statistical analyses used the Student's $t$ test or the one-way analysis of variance (ANOVA) to determine the differences between the datasets, followed by Dunnett's post-hoc 
test for multiple comparisons using SPSS ${ }^{\circledR}$ software (SPSS Inc., Chicago, IL, USA). $p<0.05$ and $p<0.005$ were considered significant.

\section{Results}

\section{Characterization of cationic nanovesicles}

As was previously reported (Nogueira et al. 2013), we assessed the effects of the dispersion medium (ultrapure water or cell culture medium) on NV hydrodynamic size (Table 2). Here, we have extended the $\mathrm{NV}$ characterization and also evaluated the effects of temperature and exposure time on the stability of the formulations in ultrapure water. DLS measurements showed that after $24 \mathrm{~h}$ incubation $\left(37^{\circ} \mathrm{C}\right)$ in ultrapure water, the NVs showed slightly lower diameters or did not consistently increase in comparison to fresh prepared NVs $(t=0)$, with the exception of the NVs containing PKM, which almost doubled in size. When the NVs were dispersed in cell culture medium (DMEM with 5\% [v/v] FBS) the size increase was slight by $0 \mathrm{~h}$, but significant agglomeration to micron-sized structures occurred after $24 \mathrm{~h}$ incubation under cell culture conditions $\left(37^{\circ} \mathrm{C}\right)$, with the exception of the NVs containing MLM. As observed from the PDI values, the increase in $\mathrm{NV}$ polydispersity was slight to moderate after $24 \mathrm{~h}$ incubation at $37^{\circ} \mathrm{C}$ in water. However, in general, substantially higher PDI values were obtained after incubation in cell culture medium. The ZP values of all formulations dispersed in water were highly positive $(>40 \mathrm{mV})$, whereas almost neutral values were obtained in cell culture medium. The NVs containing MLM showed the most positive ZP values in DMEM medium $(\sim 10 \mathrm{mV})$. The purification process with a Vivaspin column resulted in no significant changes in NV size, PDI, or ZP (data not shown). Preservation of the mean hydrodynamic size and zeta potential was observed for at least one week at $4^{\circ} \mathrm{C}$, with the exception of the formulation DMPC:CHOL:PKM, proving the generally good physical stability of these colloidal formulations. Finally, the HPLC measurements of the filtered samples (obtained from the 
purification process performed to remove the unincorporated amount of surfactant) revealed that the cationic surfactants were highly incorporated into the NVs (from 75 to $99 \%$ incorporation).

The TEM analysis (Table 2) showed that the cationic NVs containing MKM and PKM were predominantly much smaller $(\sim 20-50 \mathrm{~nm})$ than the hydrodynamic size determined by DLS ( $\sim 100$ or $200 \mathrm{~nm}$, respectively). These differences were especially significant for the NVs with MKM, while the formulations with PKM showed a more heterogeneous size distribution (2 predominant populations: $20-50 \mathrm{~nm}$ and $100-150 \mathrm{~nm}$ ). In contrast, TEM images corroborated the mean hydrodynamic size obtained by DLS for the NVs containing MLM. Moreover, the TEM images revealed the formation of a multilayered membrane in the NVs containing MLM, while those containing MKM and PKM showed unilamellar membranes in both the presence and absence of cholesterol in the basic membrane.

\section{Cytotoxicity assays}

\section{Cell viability studies}

The cytotoxicity of each surfactant in its free form was firstly assessed in 3T3 cell line (Figure 1a), in which it was observed a greater reduction of the cell viability in comparison to the correspond formulations. Thereafter, the NV effects on the viability of 3T3 (Nogueira et al. 2013) and HeLa cells were evaluated by three different endpoints (MTT, NRU and LDH). Indeed, the cytotoxic effects of NVs showed many disparities between formulations that, in fact, depended on the surfactant, cell line and endpoint assayed. These disparities can be seen in the dose-response curves illustrated in Figure 1. The NVs containing MKM and PKM induced a clear dose-dependent decrease in MTT activity (Figures 1b,c). In contrast, the NRU assay showed markedly low cytotoxicity with a significant decline in cell viability only at the highest doses assessed (> $50 \mu \mathrm{M})$ (Figures 1d,e). In the same way, the LDH release results only showed significant cytotoxicity at 50 and $100 \mu \mathrm{M}$ in $3 \mathrm{~T} 3$ cells, and to a lesser extent in HeLa cells (Figures $1 \mathrm{f}, \mathrm{g}$ ). NVs containing MLM showed relatively similar cytotoxic responses in the three 
endpoint assays. The NVs that formed agglomerates after $24 \mathrm{~h}$ incubation in cell culture medium (those containing MKM and PKM) induced more marked cytotoxic effects to the mitochondria (as shown by the MTT assay) than well-dispersed NVs (those containing MLM). NVs without any surfactant were also tested as a control of each formulation type and, as expected, it was observed that they induced negligible cytotoxic effects (Figures 1b-g). Finally, the NVs containing cholesterol were less cytotoxic to both cell lines, which might be related to the low surfactant incorporation into these formulations (Table 2). Finally, in studies of MTT and NR dye interactions with NVs, we observed only minimal interference of the NVs with the MTT dye and no interaction with the NR dye. The formulations induced only a slight increase in the MTT absorbance values at $550 \mathrm{~nm}$. These data were proved by the UV-vis measurements (data not shown).

\section{Apoptosis}

To assess the extent and mode of cell death, AO/EB staining was carried out and the samples analyzed under a fluorescence microscope. The data from this experiment revealed that the NV treatment ( $\mathrm{IC}_{50}$ concentrations) increased the number of cells undergoing apoptosis and necrosis (Figure 2a). The most significant effects were observed with the NVs containing PKM, which were also the most cytotoxic in all the viability assays. The untreated cells were observed with a green intact nuclear structure (Figure 2b), while after NV treatment we observed cells showing chromatin condensation (Figure 2c), blebbing and nuclear margination (early and moderate apoptosis) (Figures 2d,e), together with cells showing apoptotic body separation and a reddishorange color (late apoptosis) (Figure 2e) and orange nuclei with normal chromatin distribution (necrosis) (Figure 2c). 


\section{Cell cycle analysis}

In addition to the cell viability studies, flow cytometric analysis was performed to clarify the influence of each NV formulation on the cell-cycle distribution. The treatment of 3T3 cells with the $\mathrm{IC}_{20}$ and $\mathrm{IC}_{50}$ concentrations of NVs revealed no significant induction of cell cycle arrest, and only small significant changes were observed in the percentages of cells in each cell phase (Figure 3). Even the most cytotoxic NVs (those containing PKM) showed only a maximal increase in the percentage of cells in the G2/M phase from $15.15 \%$ (control) to $20.95 \%$, and a decrease in G1 and S phases from 50.19 and 32.31\% (control) to 46.71 and $27.60 \%$, respectively. Moreover, no significant cell population was observed in the sub-G1 phase, which could be attributed to the low proportion of apoptotic cells in relation to the total cell count.

\section{Genotoxicity}

DNA damage was further studied using a comet assay, by measuring the $\%$ Tail DNA in the control and treated cells. A comet-like tail implies the presence of a damaged DNA strand, and the length of the tail increases with the extent of the DNA damage (Figures 4a-c). The tested concentrations $\left(\mathrm{IC}_{10}, \mathrm{IC}_{20}\right.$ and $\left.\mathrm{IC}_{30}\right)$ of the NVs containing PKM and MLM induced significantly $(\mathrm{p}<0.005)$ higher DNA damage than the negative control (Figure 4d). However, these significant responses were $\sim 4$ - to 20 -fold lower than that induced by the positive MMS control. No clear dose-dependent response was observed among the three concentrations assessed.

\section{Oxidative damage}

MDA concentrations were measured to elucidate the lipid peroxidation induced by NVs. The NVs containing the amphiphiles MKM and PKM statistically $(\mathrm{p}<0.05)$ elevated the intracellular MDA level after $24 \mathrm{~h}$ exposure, while no significant $(\mathrm{p}>0.05)$ response was induced by the formulations containing MLM (Figure 5). The inclusion of cholesterol in the NV formulations resulted in lower MDA generation. Enhanced responses were observed as the 
concentration increased (from $\mathrm{IC}_{50} \mathrm{MTT}$ to $\mathrm{IC}_{50} \mathrm{NRU}$ ), with the exception of the formulation DMPC:CHOL:PKM. This failure in dose-dependent response might be directly attributed to the cell death. The NVs DMPC:MKM ( $\left.\mathrm{IC}_{50} \mathrm{NRU}\right)$ and DMPC:PKM $\left(\mathrm{IC}_{50}\right.$ MTT and NRU) showed the most prominent responses, as they elevated intracellular MDA to concentrations higher than that induced by the positive $\mathrm{H}_{2} \mathrm{O}_{2}$ control.

\section{Blood compatibility studies}

The hemocompatibility of the cationic NVs was studied by hemolysis experiments. The release of hemoglobin was used to quantify the erythrocyte-damaging properties of the NVs. The hemolytic activity of the NVs, with concentrations up to $200 \mu \mathrm{M}$, was negligible (less than $5 \%$ ) after $10 \mathrm{~min}$ incubation (data not shown). When the hemolysis assay was performed for $1 \mathrm{~h}$ (Figure 6a), the formulations containing MKM showed increased hemolysis at $100 \mu \mathrm{M}$, while the NVs containing PKM only prompted enhanced hemolysis at $200 \mu \mathrm{M}$. NVs containing MLM did not increase the hemolytic activity at any concentration assayed. Moreover, the NVs containing MKM and MLM did not induce agglutination of erythrocytes after $1 \mathrm{~h}$ of treatment (Figures 6b-h), whereas a slight tendency to agglutinate was noticed with the NVs containing PKM (Figures 6e,f).

The plasma proteins adsorbed to the NVs were firstly evaluated by SDS-PAGE. In brief, we analyzed the plasma protein present in the supernatant after incubation with NVs. Figure $6 \mathrm{i}$ shows the protein banding patterns that appeared after electrophoresis. No qualitative differences were observed in any protein band in comparison to the control plasma sample, which indicates that a negligible or very small amount of plasma protein was adsorbed onto the NVs following incubation under in vitro conditions. To further examine the plasma protein adsorption, we assessed the proteins desorbed from the NVs surface, obtained from washed particle pellets. The gel of the proteins adsorbed to NVs from $10 \%$ plasma is shown in Figure $6 \mathrm{j}$. The lane corresponding to the final wash fluid shows essentially no protein, which confirms that 
the wash protocol reduced unbound protein to an insignificant level. No substantial amount of protein was associated with the NVs after plasma contact, which indicates the lack of nonspecific adsorption. We only observed quite a faint band in the $50-75 \mathrm{kDa}$ range of the gel, which corresponds to albumin $(67 \mathrm{kDa})$, the most abundant plasma protein. Moreover, it seems that the albumin adsorption was higher in the formulations containing cholesterol (Figures $6 \mathrm{j}$, lanes 2, 4 and 6). Finally, quantitative analyses of total protein adsorption were performed using the BioRad assay. In agreement with the qualitative data obtained from the SDS-PAGE gels, no significant differences were observed in the amount of protein in the control plasma and NVtreated plasma (data not shown).

\section{Cell uptake studies and pH-dependent membrane-lytic activity of NVs}

The cell uptake of fluorescent-labelled NR-NVs by the HeLa cell line was visualized by a fluorescence microscope after $2 \mathrm{~h}$ and $24 \mathrm{~h}$ incubation (Figure 7A). Fluorescent punctate spots were observed mainly in the cell cytosol, which indicates that the NVs were taken up by the cells. Moreover, a smaller number of fluorescent spots were detected along the cell membrane, but not in the nucleus. Interestingly, $24 \mathrm{~h}$ of incubation resulted in a more intensive dotted pattern of fluorescent NVs inside the cell, together with some diffuse fluorescence in the cytosol. The quantitative analysis of the images corroborated the greater localization of the NVs in the intracellular compartments after $24 \mathrm{~h}$ of incubation (Figure $7 \mathrm{C}$ ). The cell uptake was $\sim 2$ fold higher than after $2 \mathrm{~h}$ of incubation $(\mathrm{p}<0.005)$.

The ability of NVs to release endocytosed materials into cell cytoplasm was examined by fluorescence microscopy following uptake of calcein and NVs into HeLa cells (Figure 7B). Cells treated with calcein alone (control cells) showed a punctuate distribution of fluorescence, which is consistent with constitutive endocytosis of the external medium. Moreover, the coincubation of calcein and NVs containing MLM only induced a low release of calcein from endosomal compartments. Almost all of the membrane-impermeable fluorophore was restricted 
within intracellular vesicles appearing as bright punctate structures in a similar level of the control cells. In contrast, when the cells were co-incubated with calcein and NVs containing MKM or PKM, green diffuse fluorescence staining was observed in the cytoplasm, which indicates that calcein had been released from the endosomes. Stronger diffuse staining in the cytoplasm was observed after cell treatment with the NVs containing MKM, whilst a larger number of bright intact vesicles still existed after cell treatment with the NVs containing PKM. Figure 7D shows the quantitative analyses of the cytosolic calcein distribution., which corroborate that the NVs containing MKM or PKM induced significant endosomal destabilization and calcein release $(\mathrm{p}<0.005)$, whereas those containing MLM prompted low or negligible membrane-lytic activity at the endosomal compartments $(\mathrm{p}<0.05$ for DMPC:MLM and $\mathrm{p}>0.05$ for DMPC:CHOL:MLM). The presence of cholesterol confers to each formulation a low ability to lysis the endosomal membrane, which can be attributed to the low incorporation of the surfactants into the NV lipid-based structure.

\section{Discussion}

Chemical composition of the NMs is one of the most important factors influencing cellular interaction. Therefore, the role of including cationic amphiphiles in lipid-based NVs was investigated. We hypothesised that these compounds influences not only the cytotoxic effects, but also the physicochemical properties and intracellular behavior after cell uptake. In order to corroborate this hypothesis, we prepared six different NVs formulations containing three lysinebased surfactants that differ in the cationic charge position and hydrophobicity.

NV hydrodynamic size characterization in cell culture medium suggested significant agglomeration, especially for formulations containing MKM and PKM (positive charge on the $\alpha$-amino group of lysine). These amphiphiles have $\mathrm{pKa}$ values of 5.3 and 4.5 (Nogueira et al. 2012a), respectively, which means that at physiological conditions they predominantly exist as unprotonated species and, therefore, the resulting NVs tend to aggregate. The tendency of NMs 
to agglomerate in cell culture medium during an in vitro toxicity assessment has been previously reported (Horie et al. 2012; Monteiro-Riviere et al. 2009, 2010). The easy aggregation or agglomeration in cell culture medium is probably attributed to the high ionic nature of the solution and the electrostatic/van der Waals interaction between protein and NMs, which result in the formation of secondary particles (Horie et al. 2012). In contrast, NVs containing MLM (positive charge on the $\varepsilon$-amino group of lysine) were not agglomerated in the cell culture medium. This may be due to their higher charge density at physiological $\mathrm{pH}(\mathrm{pKa}$ MLM $=8.1$ ), corroborated by the ZP values determined in the cell culture medium. A high charge density increases the physical stability of colloidal dispersions (Liang et al. 2009). These overall findings showed that the cationic charge position in the amphiphile determines the aggregation state of NVs. The high positive ZP values of the NVs in water indicated the stability of the prepared formulations by preventing fusion or aggregation of NVs (Liang et al. 2009). A physically stable formulation would have a minimum $\pm 30 \mathrm{mV} \mathrm{ZP}$ as a borderline value of colloidal stability (Di Marzio et al. 2011; Müller et al. 2011). Interestingly, the mean hydrodynamic diameters measured by DLS did not capture the real size distribution of the NVs observed by TEM. DLS measurements of NVs containing MKM and PKM were larger than those determined from the TEM images of the corresponding samples. Disparity between DLS and TEM might be a result of the resolution limitations of DLS (Coldren et al. 2003; Ojogun et al. 2009), aggregation (Ahmad et al. 2012; Bai et al. 2009; Venkatesan et al. 2011) and swelling of the NVs in the presence of water (Mehrotra et al. 2011), or even to the fact that DLS gives the mean hydrodynamic diameter of the particle core surrounded by the solvation layers, whereas TEM gives the diameter of particles alone in the dry state (Gao et al. 2010).

High throughput cell-based tests have been the initial step in biological screening approaches (Monteiro-Riviere et al. 2009). Moreover, in vitro cell culture-based cytotoxicity screening assays, designed to minimize animal use in toxicity testing, have become and are 
expected to remain the mainstay of modern toxicology testing strategies (National Research Council 2007). The use of model cell lines from different origins and more than one cytotoxicity assay is a reliable approach to systematically investigate the influence of NM properties on the degrees and pathways of cytotoxicity (Bhattacharjee et al. 2013; Fröhlich et al. 2012; Sohaebuddin et al. 2010). 3T3 cell model is considered very sensitive to verify in vitro cytotoxic effects of NMs (Uboldi et al. 2012; Mahto et al. 2010), while HeLa tumor cell line is a culture model widely used in cytotoxicity and especially in cell uptake studies of a broad range of particulate nanocarriers (Kelsch et al. 2012; Salado et al. 2012). The tumor HeLa cell line was more resistant to NV cytotoxic effects, which was in agreement with our previous study (Nogueira et al. 2011b). These results are also in line with those reported by several authors (Fröhlich et al. 2012; Müller et al. 1997; Schöler et al. 2001; Sohaebuddin et al. 2010; Xia et al. 2008), who noticed that the cytotoxic effects of particulate carrier systems differ depending on the cell lines used, due to the innate nature, metabolic abilities (e.g. enzymes present) and capabilities of the cell lines. In an attempt to understand the toxic response of NMs, here we used different cytotoxicity assays. The higher sensitivity of the MTT assay for detecting the cytotoxic effects of the NVs containing MKM and PKM suggests that the cytotoxicity primarily originated at the mitochondrial compartment after cellular internalization of NVs rather than physical damage to both lysosomal (NRU assay) and plasma (LDH assay) membranes (Yang et al. 2009). Noteworthy is that the intracellular reactions of internalized NMs were reported to lead to cellular metabolism/mitochondrial dysfunction (Horie et al. 2012). Concerning to cell membrane integrity, we observed different effects when the cell line was varied, being NRU assay more sensitive in HeLa cells and LDH in $3 \mathrm{~T} 3$ fibroblasts. These results corroborated the different interaction mechanisms of these NVs within cells from different origins and species. In contrast, NVs formulated with MLM generally displayed the same level of cytotoxicity with the three endpoints. These NVs have higher positive ZP in cell culture medium, which might 
support their higher binding to the negatively charged lipid bilayer by electrostatic interaction and, thus, their toxic effects on the cell membrane to the same extent as cell metabolism depletion (Venkatesan et al. 2011; Xia et al. 2008). All in all, these results led to a key finding of our research: the structural characteristic of the surfactant included in the NV directly affects its cytotoxic effects. Firstly, the position of the cationic charge in the amphiphile molecule was critical in determining the resulting formulation's cytotoxicity. Secondly, the hydrophobicity of the surfactant was directly related to the NV toxic effects: the longer the alkyl chain of the amphiphile, the higher the NV cytotoxicity. Based on the variability of cell responses, a combination of cell lines and endpoints might be suitable for a reliable in vitro evaluation of nanotoxicity. Finally, the small interference of the NVs with the MTT dye did not result in further increase in cell viability with increasing NM concentration, which is in contrast to previous reported data for other types of NMs (Monteiro-Riviere et al. 2009, 2010). These data prove that these small interactions were no significant and, therefore, that the viability endpoints are suitable for the intended purpose.

After showing that NVs exerted cytotoxic effects on the proliferation of fibroblasts in a typically dose-dependent manner, we examined whether the induction of apoptosis was the possible molecular mechanism involved in the cytotoxicity of NVs. Morphological alterations detected after staining with $\mathrm{AO} / \mathrm{EB}$ demonstrated that the $\mathrm{NV}$ treatments could induce apoptosis in cultured fibroblasts. Whereas the apoptotic effects could be attributed to the observed induction of oxidative damage (AshaRani et al. 2009), mitochondrial dysfunction, which can be determined by MTT assay (Fisher et al. 2003), is reported as an intrinsic pathway of apoptosis. Therefore, the apoptotic effects of the NVs containing especially MKM and PKM can be directly related to oxidative stress and early mitochondrial injury. Additionally, plasma membrane integrity modifications that are detected by LDH assay could be related to the late stage of apoptosis (Fisher et al. 2003) and necrosis. Recent reports have identified apoptosis as a 
major mechanism of cell death in exposure to NMs (Hsin et al. 2008; Pan et al. 2007). However, in our case, although the number of apoptotic cells increased, most cells remained viable after NV treatments. This suggests that other factors also contribute to cell death, aside from the apoptotic pathway.

Toxicity studies were further extended to cell-cycle analysis, which showed that NV treatment did not induce many significant alterations, as the cell cycle distribution was very similar to the control. This suggests that cell cycle arrest is not the mechanism underlying NV cytotoxicity. In this line, genotoxicity did not appear to be one of the main mechanisms involved in NV toxic effects. Although some significant values of \% Tail DNA were obtained with respect to the negative control, the overall responses can be considered biologically nonsignificant, as the $\%$ values were close to the negative control values and much lower than those displayed by the positive MMS control. These results are in agreement with the cell cycle analysis, as, if present, DNA damage would be evidenced in cell cycle progression with the accumulation of cells in a determined cycle phase (AshaRani et al. 2009).

NMs might be able to disturb the oxidative balance in a cellular environment. This phenomenon is called oxidative stress and results in abnormally large concentrations of intracellular reactive oxygen species (ROS) (Marquis et al. 2009). In response to oxidative stress, cell surface and organelle membrane lipids may undergo peroxidation (Choi et al. 2007). A marker of lipid peroxidation elicited by ROS is increased MDA production, which was induced by the NVs containing MKM or PKM. The inverse correlation between cell viability and MDA level made the latter a key analytical marker for induced cell damage, which in turn indicated that oxidative stress was probably a key route by which these NVs induce cytotoxicity. ROS-induced membrane lipid peroxidation may occur both at cellular and organelle levels, especially in the membranes of metabolically active mitochondria. This makes mitochondrial injury a marker of elevated intracellular ROS level (Choi et al. 2007; Jones and Grainger 2009). 
The early compromised cell viability detected by the MTT reduction assay may also result from this insult.

Intravenous administration of a nanocarrier is limited by its hemolytic activity, among other factors. Thus, hemolysis should be assessed to determine the biocompatibility of a material (He et al. 2009). The low hemolytic activity of NVs at concentrations that were also noncytotoxic $(<100 \mu \mathrm{M})$ indicated the hemocompatibility of the formulations. Generally, a percentage of hemolysis of less than 5\% was regarded as non-toxic (He et al. 2009). Moreover, the strong positive charge of the NVs did not induce erythrocyte agglutination. This is in contrast to previous reported data for cationic carriers (Eliyahu et al. 2002), but corroborates the hemocompatible properties of the NVs. The NVs were more toxic to 3T3 and HeLa cells than to erythrocytes. This greater sensitivity may reflect differences in intrinsic structural properties of membranes and might be attributed to the fact that erythrocytes cannot internalize foreign particles, which leads to poor insertion into the phospholipid membrane and consequently low hemolytic activity (Yessine et al. 2003). Furthermore, protein adsorption on particulate drug carriers is regarded as a key factor for their in vivo fate and might also play an important role in directing their cell uptake and toxicity (Dutta et al. 2007). Minimal differences in protein pattern were observed after plasma incubation with NVs. This indicates that negligible or very small amount of plasma protein was adsorbed onto NVs following incubation under in vitro conditions. Overall, our results showed that the NVs positive charge, attributed to the surface modification with cationic lysine-based amphiphiles, did not compromise the desirable blood compatibility of the lipid-based vesicles.

The therapeutic effects of the drug-loaded NMs would firstly depend on internalization by the diseased cells (Mei et al. 2009). Here, the observed punctuate distribution of fluorescence in the cell cytosol indicated the cell uptake of the NR-NVs. The more intense fluorescence at 24 $\mathrm{h}$ indicated a higher cell uptake after a longer incubation time, whereas the diffuse fluorescence 
in the cytosol can be attributed to dye release after endosome rupture. Internalization is probably mediated through an endocytic pathway through non-specific interactions (e.g., adsorptive endocytosis) with cell membrane (Park et al. 2006). Moreover, the results obtained after the concomitant cell incubation with calcein and NV suggest that the NMs entered the cell by endocytosis (see discussion below). Noteworthy is that the formation of secondary vesicles due to aggregation in cell culture medium did not inhibited their cellular uptake. Finally, and in relation to the toxic effects of NVs, the hydrophobicity (Arora et al. 2012) and the electrostatic interactions between the cationic NVs and the anionic cell surface (Venkatesan et al. 2011) might be responsible for the cell uptake.

The high efficiency of amphiphiles with a positive charge on the $\alpha$-amino group of lysine (MKM and PKM) at disrupting cell membranes within the $\mathrm{pH}$ range characteristic of late endosomes (Nogueira et al. 2012a) prompted an evaluation of the ability of NVs containing these compounds to release endocytosed materials into the cytoplasm of cells. One common strategy for the intracellular delivery of encapsulated and/or intercalated material via lipid-based vesicles exploits intracellular pH gradients (Pollock et al. 2010; Torchilin et al. 1993). We used calcein as a tracer molecule, which is internalized by the cell through endocytosis and is used to monitor the stability of endosomes following NM uptake (Hu et al. 2007). In the absence of $\mathrm{NVs}$, endosomal compartmentalization of calcein was observed, indicating that the endosome membranes were not damaged (Chen et al. 2009; Hu et al. 2007). When the MLM was included into the NVs, it was observed a different behavior depending on the composition of the basic lipid membrane. Only the formulations without cholesterol had the ability to release some calcein from endosomes, which can be due to a non specific interaction between these NVs and the endosomal membrane. In contrast, the NVs containing MKM and PKM induced efficient and greater release of endocytosed material into the cytoplasm regardless of the composition of the lipid-based matrix. These results corroborated the $\mathrm{pH}$-responsive membrane-lytic activity of 
the latter surfactants demonstrated in our previous study (Nogueira et al. 2012a). Since MKM and $\mathrm{PKM}$ are more protonated at acidic $\mathrm{pH}(\mathrm{pka}=5.3$ and 4.5 , respectively), they might interact with negatively-charged endosomal membranes, induce influx of water and ions, and eventually bring about endosome destabilization and drug release (Park et al. 2006). The stronger diffuse staining observed after cell treatment with the NVs containing MKM may be directly related to the higher membrane-lytic activity of MKM at the $\mathrm{pH}$ range characteristic of the endosomal compartments (Nogueira et al. 2012a). The efficient intracellular delivery of therapeutic compounds into the cytosol by destabilizing endosomal membranes under mildly acidic conditions would manipulate or circumvent non-productive trafficking from endosomes to lysosomes, in which degradation may occur (Chen et al. 2009).

All considered, these data on the cytotoxic pathways and intracellular behavior show a structure-activity relationship of the cellular events in response to NVs, which is summarized in Table 3. The main finding is that the position of the cationic charge in surfactant molecule determines the NV cytotoxic responses, induction of oxidative stress, endosomal release and hemolytic activity. NVs containing the surfactants with cationic charge on the $\alpha$-amino group of lysine affect firstly the mitochondria, followed by the lysosomal and plasma membrane, as demostrated by the corresponding in vitro endpoints. Moreover, the surfactant hydrophobicity correlates directly with the cytotoxic and genotoxic effects. In contrast, the surfactant chemical structure does not affect the NV effects on apoptosis, cell cycle, erythrocyte agglutination and plasma protein adsorption.

Finally, it is appropriate to comment on the importance of these findings for nanotoxicology. Here, we showed that some NVs have the ability to lysis the endosomal membrane and are therefore potential carriers for specific intracellular drug delivery. However, we also demonstrated that they have an effect on normal cell biological functions and that such effect is presented in terms of various toxic mechanisms. We must highlight the in vitro 
approach used in this study as a reliable predictive model to provide an affordable database on the biological activities of new NMs as a function of their chemical composition, which would help understand their risks and opportunities before any in vivo application. An initial animalbased screening approach is not feasible with regard to laboratory capacities and costs, and it certainly is not desirable from an animal welfare viewpoint (Hartung 2010). Relevant in vitro data may suggest the feasibility of new NMs for further applications. Therefore, only the NMs with such relevance must be addressed for additional in vivo studies to corroborate the initial hypothesis demonstrated through in vitro screening assays.

\section{Conclusions}

Here, we used an in vitro toxicological approach to elucidate the biological activity and intracellular behavior of new cationic NV formulations containing biocompatible lysine-based amphiphiles. We demonstrated the cell-specific nature of NV toxicity as well as different toxic responses when the in vitro endpoint varied. A possible mechanism of toxicity is proposed involving NV cell uptake followed by induction of oxidative stress, which in turn cause mitochondrial dysfunction and ultimately result in apoptosis of cells. This mechanism is especially proposed as the cytotoxicity pathway induced by the NVs containing MKM and PKM, as those with MLM did not prompt significant oxidative stress and mitochondrial injury. The cytotoxicity of the latter NVs seems to be attributed to an initial damage to the cell membranes. NV cytotoxicity as well as their cellular uptake might be attributable to the cationic charge. Our findings suggest that the cationic charge position and hydrophobicity of the amphiphiles determine the NV interaction within the cell and, thus, their resulting toxicity and intracellular behavior after cell uptake. NVs containing MKM and PKM (with a cationic charge on the $\alpha$-amino group of lysine) are especially recommended as $\mathrm{pH}$-sensitive nanocarriers for intracellular drug delivery. They have the ability to specifically lyse the endosome membrane in mildly acidic conditions, as evidenced here and demonstrated in our preliminary study 
(Nogueira el al. 2012a). Desirable blood compatibility was substantiated by minimal interaction with erythrocytes and lack of plasma protein adsorption, which also corroborates the potencial application of these NVs as carriers of intravenous biomedical drugs that have their site of action in the intracellular compartments. However, we are aware that further in vivo studies must be conducted in this field to prove this hypothesis. Finally, as each NM type shows unique physicochemical properties, the combination of assays used here, together with all the information provided, offers an in-depth and comprehensive evaluation of the toxic effects of novel NMs and contributes to reducing the uncertainty surrounding their potential health hazards.

\section{Acknowledgments}

This research was supported by Projects CTQ2009-14151-C02-02 and CTQ2009-14151-C02-01 of the Ministerio de Ciencia e Innovación (Spain), and MAT2012-38047-C02-01 of the Ministerio de Economía y Competitividad (Spain). We also thank Dr. Núria Cortadellas and Dr. Jaume Comas for their expert technical assistance with the TEM and flow cytometry experiments, respectively. Daniele Rubert Nogueira holds a PhD grant from MAEC-AECID (Spain).

\section{Declaration of interest}

The authors state that they have no conflict of interest. 


\section{References}

Ahmad J, Ahamed M, Akhtar MJ, Alrokayan SA, Siddiqui M, Musarrat J, Al-Khedhairy AA. 2012. Apoptosis induction by silica nanoparticles mediated through reactive oxygen species in human liver cell line HepG2. Toxicol Appl Pharmacol 259:160-168.

Arora S, Rajwade JM, Paknikar KM. 2012. Nanotoxicology and in vitro studies: The need of the hour. Toxicol Appl Pharmacol 258:151-165.

AshaRani PV, Mun GLK, Hande MP, Valiyaveettil S. 2009. Cytotoxicity and genotoxicity of silver nanoparticles in human cells. ACS Nano 3:279-290.

Bai W, Zhang Z, Tian W, He X, Ma Y, Zhao Y, Chai Z. 2009. Toxicity of zinc oxide nanoparticles to zebrafish embryo: a physicochemical study of toxicity mechanism. J Nanopart Res 12:1645-1654.

Bhattacharjee S, Ershov D, van der Gucht J, Alink GM, Rietjens IMCM, Zuilhof H, Marcelis ATM. 2013. Surface charge-specific cytotoxicity and cellular uptake of tri-block copolymer nanoparticles. Nanotoxicology 7:71-84.

Bombelli C, Caracciolo G, Di Profio P, Diociaiuti M, Luciani P, Mancini G, Mazzuca C, Marra M, Molinari A, Monti D, Toccacieli L, Venanzi M. 2005. Inclusion of a photosensitizer in liposomes formed by DMPC/Gemini Surfactant: Correlation between physicochemical and biological features of the complexes. J Med Chem 48:4882-4891.

Bradford MM. 1976. A rapid and sensitive method for quantitation of microgram quantities of protein utilizing the principle of protein-dye binding. Anal Biochem 72:248-254.

Cevc G. 2012. Rational design of new product candidates: The next generation of highly deformable bilayer vesicles for noninvasive, targeted therapy. J Control Release 160:135-146.

Chen R, Khormaee S, Eccleston ME, Slater NKH. 2009. The role of hydrophobic amino acid grafts in the enhancement of membrane-disruptive activity of $\mathrm{pH}$-responsive pseudo-peptides. Biomaterials 30:1954-1961.

Chen T, McIntosh D, He Y, Kim J, Tirrell DA, Scherrer P, Fenske D, Sandhu AP, Cullis PR. 2004. Alkylated derivatives of poly(ethylacrylic acid) can be inserted into preformed liposomes and trigger $\mathrm{pH}$-dependent intracellular delivery of liposomal contents. Mol Membr Biol 21:385-393. 
Choi AO, Cho SJ, Desbarats J, Lovric J, Maysinger D. 2007. Quantum dot-induced cell death involves Fas upregulation and lipid peroxidation in human neuroblastoma cells. J Nanobiotechnol 5:1.

Coldren B, van Zanten R, Mackel MJ, Zasadzinski J.A. 2003. From Vesicle Size Distributions to Bilayer Elasticity via Cryo-Transmission and Freeze-Fracture Electron Microscopy. Langmuir 19:5632-5639.

Collins TJ. 2007. ImageJ for microscopy. BioTechniques 43:S25-S30.

Colomer A, Pinazo A, Garcia T, Mitjans M, Vinardell P, Infante MR, Martínez V, Pérez L. 2012. pH sensitive surfactants from lysine: assessment of their cytotoxicity and environmental behavior. Langmuir 28:5900-5912.

Dakwar GR, Hammad IA, Popov M, Linder C, Grinberg S, Heldman E, Stepensky D. 2012. Delivery of proteins to the brain by bolaamphiphilic nao-sized vesicles. J Control Release $160: 315-321$.

Di Guglielmo C, De Lapuente J, Porredon C, Ramos-López D, Sendra J, Borràs M. 2012. In Vitro Safety Toxicology Data for Evaluation of Gold Nanoparticles-Chronic Cytotoxicity, Genotoxicity and Uptake. J Nanosci Nanotechnol 12:1-6.

Di Marzio L, Marianecci C, Petrone M, Rinaldi F, Carafa M. 2011. Novel pH-sensitive nonionic surfactant vesicles: comparison between Tween 21 and Tween 20. Colloids Surf B Biointerfaces $82: 18-24$

Dutta D, Sundaram SK, Teeguarden JG, Riley BJ, Fifield LS, Jacobs JM. 2007. Adsorbed proteins influence the biological activity and molecular targeting of nanomaterials. Toxicol Sci 100:303-315.

Eliyahu H, Servel N, Domb AJ, Barenholz Y. 2002. Lipoplex-induced hemagglutination: potential involvement in intravenous gene delivery. Gene Ther 9:850-858.

Fisher D, Li Y, Ahlemeyer B, Krieglstein J, Kissel T. 2003. In vitro cytotoxicity testing of polycations: influence of polymer structure on cell viability and hemolysis. Biomaterials 24:1121-1131.

Fröhlich E, Meindl C, Roblegg E, Griesbacher A, Pieber TR. 2012. Cytotoxicity of nanoparticles is influenced by size, proliferation and embryogenic origin of the cells used for testing. Nanotoxicology 6:424-439. 
Gao F, Cai Y, Zhou J, Xie X, Ouyang W, Zhang Y, Wang X, Zhang X, Wang X, Zhao L, Tang J. 2010. Pullulan acetate coated magnetic nanoparticles for hyperthermia: preparation, characterization and in vitro experiments. Nano Res 3:23-31.

Hartung T. 2010. Food and thought....on alternative methods for nanoparticle safety testing. ALTEX 27:87-95.

He M, Zhao Z, Yin L, Tang C, Yin C. 2009. Hyaluronic acid coated poly(butyl cyano-acrylate) nanoparticles as anticancer drug carriers. Int J Pharm 373:165-173.

Horie M, Kato H, Fujita K, Endoh S, Iwahashi H. 2012. In vitro evaluation of cellular response induced by manufactured nanoparticles. Chem Res Toxicol 25:605-619.

Hsin YH, Chen CF, Huang S, Shih TS, Lai PS, Chueh PJ. 2008. The apoptotic effect of nanosilver is mediated by a ROS- and JNK-dependent mechanism involving the mitochondrial pathway in NIH3T3 cells. Toxicol Lett 179:130-139.

Hu Y, Litwin T, Nagaraja AR, Kwong B, Katz J, Watson N, Irvine DJ. 2007. Cytosolic delivery of membrane-impermeable molecules in dendritic cells using $\mathrm{pH}$-responsive core-shell nanoparticles. Nano Lett 7:3056-3064.

Infante MR, Pérez L, Morán MC, Pons R, Mitjans M, Vinardell MP, Garcia MT, Pinazo A. 2010. Biocompatible surfactants from renewable hydrophiles. Eur J Lipid Sci Technol $112: 110-121$.

Jones RA, Cheung CY, Black FE, Zia JK, Stayton PS, Hoffman AS, Wilson MR. 2003. Poly(2alkylacrylic acid) polymers deliver molecules to the cytosol by $\mathrm{pH}$-sensitive disruption of endosomal vesicles. Biochem J 372:65-75.

Jones CF, Grainger DW. 2009. In vitro assessments of nanomaterial toxicity. Adv Drug Deliv Rev 61:438-456.

Kelsch A, Tomcin S, Rausch K, Barz M, Mailänder V, Schmidt M, Landfester K, Zentel R. 2012. HPMA copolymers as surfactants in the preparation of biocompatible nanoparticles for biomedical application. Biomacromolecules 13:4179-4187.

Liang C-H, Chou T-H. 2009. Effect of chain length on physicochemical properties and cytotoxicity of cationic vesicles composed of phosphatidylcholines and dialkyldimethylammonium bromides. Chem Phys Lip 158:81-90. 
Lundberg D, Faneca H, Morán MC, Lima MCP, Miguel MG, Lindman B. 2011. Inclusion of a single-tail amino acid-based amphiphile in a lipoplex formulation: Effects on transfection efficiency and physicochemical properties. Mol Membr Biol 28:42-53.

Mahto SK, Park C, Yoon TH, Rhee SW. 2010. Assessment of cytocompatibility of surfacemodified CdSe/ZnSe quantum dots for BALB/3T3 fibroblast cells. Toxicol in vitro 24:10701077.

Marquis BJ, Love SA, Braun KL, Haynes CL. 2009. Analytical methods to assess nanoparticle toxicity. Analyst 134:425-439.

Mehrotra A, Nagarwal RC, Pandit JK. 2011. Lomustine loaded chitosan nanoparticles: characterization and in-vitro cytotoxicity on human luna cancer cell line L132. Chem Pharm Bull 59:315-320.

Mei L, Zhang Y, Zheng Y, Tian G, Song C, Yang D, Chen H, Sun H, Tian Y, Liu K, Li Z, Huang L. 2009. A novel docetaxel-loaded poly ( $\varepsilon$-caprolactone)/pluronic F68 nanoparticle overcoming multidrug resistance for breast cancer treatment. Nanoscale Res Lett 4:15301539.

Monteiro-Riviere NA, Inman AO, Zhang LW. 2009. Limitations and relative utility of screening assays to assess engineered nanoparticle toxicity in a human cell line. Toxicol Appl Pharmacol 234:222-235.

Monteiro-Riviere NA, Oldenburg SJ, Inman AO. 2010. Interactions of aluminum nanoparticles with human epidermal keratinocytes. J Appl Toxicol 30:276-285.

Morán MC, Infante MR, Miguel MG, Lindman B, Pons R. 2010. Novel Biocompatible DNA Gel Particles. Langmuir 26:10606-10613.

Müller RH, Jacobs C, Kayser O. 2011. Nanosuspensions as particulate drug formulations in therapy. Rationale for development and what we can expect for the future. Adv Drug Deliv Rev 23:3-19.

Müller RH, Rühl D, Runge SA, Schulze-Forster K, Mehnert W. 1997. Cytotoxicity of solid lipid nanoparticles as a function of the lipid matrix and the surfactant. Pharm Res 14:458-462.

National Research Council (2007). Toxicity testing in the twenty-first century: a vision and strategy. National Academy Press, Washington, DC. 
Nogueira DR, Mitjans M, Infante MR, Vinardell MP. 2011a. The role of counterions in the membrane-disruptive properties of $\mathrm{pH}$-sensitive lysine-based surfactants. Acta Biomater 7:2846-2856.

Nogueira DR, Mitjans M, Infante MR, Vinardell MP. 2011b. Comparative sensitivity of tumor and non-tumor cell lines as a reliable approach for in vitro cytotoxicity screening of lysinebased surfactants with potential pharmaceutical applications. Int J Pharm 420:51-58.

Nogueira DR, Mitjans M, Morán MC, Pérez L, Vinardell MP. 2012a. Membrane-destabilizing activity of $\mathrm{pH}$-responsive cationic lysine-based surfactants: role of charge position and alkyl chain length. Amino Acids 43:1203-1215.

Nogueira DR, Mitjans M, Busquets MA, Pérez L, Vinardell MP. 2012b. Phospholipid bilayer perturbing-properties underlying lysis induced by $\mathrm{pH}$-sensitive cationic lysine-based surfactants in biomembranes. Langmuir 28:11687-11698.

Nogueira DR, Morán MC, Mitjans M, Martínez V, Pérez L, Vinardell MP. 2013. New cationic nanovesicular systems containing lysine-based surfactants for topical administration: toxicity assessment using representative skin cell lines. Eur J Pharm Biopharm 83:33-43.

Ojogun VA, Lehmler H-J, Knutson BL. 2009. Cationic-anionic vesicle templating from fluorocarbon/fluorocarbon and hydrocarbon/fluorocarbon surfactants. J Coll Interf Sci 338:82-91.

Paillard A, Hindré F, Vignes-Colombeix C, Benoit J-P, Garcion E. 2010. The importance of endo-lysosomal escape with lipid nanocapsules for drug subcellular bioavailability. Biomaterials 31:7542-7554.

Pan Y, Neuss S, Leifert A, Fischler M, Wen F, Simon U, Schmid G, Brandau W, JahnenDechent W. 2007. Size-dependent cytotoxicity of gold nanoparticles. Small 3:1941-1949.

Park JS, Han TH, Lee KY, Han SS, Hwang JJ, Moon DH, Kim SY, Cho YW. 2006. N-acetyl histidine-conjugated glycol chitosan self-assembled nanoparticles for intracytoplasmic delivery of drugs: endocytosis, exocytosis and drug release. J Control Release 115:37-45.

Pérez L, Pinazo A, García MT, Lozano M, Manresa A, Angelet M, Vinardell MP, Mitjans M, Pons R, Infante MR. 2009. Cationic surfactants from lysine: Synthesis, micellization and biological evaluation. Eur J Med Chem 44:1884-1892. 
Pollock S, Antrobus R, Newton L, Kampa B, Rossa J, Latham S, Nichita NB, Dwek RA, Zitzmann N. 2010. Uptake and trafficking of liposomes to the endoplasmic reticulum. FASEB J 24:1866-1878.

Ramezani M, Khoshhamdam M, Dehshahri A, Malaekeh-Nikouei B. 2009. The influence of size, lipid composition and bilayer fluidity of cationic liposomes on the transfection efficiency of nanolipoplexes. Colloids Surf B Biointerfaces 72:1-5.

Rasband W, (1997). ImageJ. National Institutes of Health, Bethesda, MD, USA. Available at: http://rsbweb.nih.gov/ij/index.html. Accessed on 9 January 2013

Robbens J, Vanparys C, Nobels I, Blust R, Hoecke KV, Janssen C, Schamphelaere KD, Roland K, Blanchard G, Silvestre F, Gillardin V, Kestemont P, Anthonissen R, Toussaint O, Vankoningsloo S, Saout C, Alfaro-Moreno E, Hoet P, Gonzalez L, Dubruel P, Troisfontaines P. 2010. Eco-, geno-, and human toxicology of bio-active nanoparticles for biomedical applications. Toxicology 269:170-181.

Salado J, Insausti M, Lezama L, Gil de Muro I, Moros M, Pelaz B, Grazu V, Fuente JM, Rojo T. 2012. Functionalized $\mathrm{Fe}_{3} \mathrm{O}_{4} @ \mathrm{Au}$ superparamagnetic nanoparticles: in vitro bioactivity. Nanotechnology 23:315102.

Schöler N, Olbrich C, Tabatt K, Müller RH, Hahn H, Liesenfeld O. 2001. Surfactant, but not the size of solid lipid nanoparticles (SLN) influences viability and cytokine production of macrophages, Int J Pharm 221:57-67.

Simões S, Moreira JN, Fonseca C, Düzgünes N, Lima MC. 2004. On the formulation of pHsensitive liposomes with long circulation times. Adv Drug Deliv Rev 56:947-965.

Singh NP, McCoy MT, Tice EL, Schneider EL. 1988. A simple technique for quantitation of low levels of DNA damage in individual cells. Exp Cell Res 175:184-191.

Sohaebuddin SK, Thevenot PT, Baker D, Eaton JW, Tang L. 2010. Nanomaterial cytotoxicity is composition, size, and cell type dependent. Part Fibre Toxicol 7:22.

Squier MKT, Cohen JJ. 2001. Standard quantitative assays for apoptosis. Mol Biotechnol 19:305-312.

Torchilin VP, Zhou F, Huang L. 1993. pH-sensitive liposomes. J Liposome Res 3:201-255.

Uboldi C, Giudetti G, Broggi F, Gilliland D, Ponti J, Rossi F. 2012. Amorphous silica nanoparticles do not induce cytotoxicity, cell transformation or genotoxicity in Balb/3T3 mouse fibroblasts. Mutat Res 745:11-20. 
Venkatesan P, Puvvada N, Dash R, Kumar BNP, Sarkar D, Azab B, Pathak A, Kundu SC, Fisher PB, Mandal M. 2011. The potential of celecoxib-loaded hydroxyapatite-chitosan nanocomposite for the treatment of colon cancer. Biomaterials 32:3794-3806.

Xia T, Kovochich M, Liong M, Zink JI, Nel AE. 2008. Cationic polystyrene nanosphere toxicity depends on cell-specific endocytic and mitochondrial injury pathways. ACSNano 2:85-96.

Yang H, Liu C, Yang D, Zhang H, Xi Z. 2009. Comparative study of cytotoxicity, oxidative stress and genotoxicity induced by four typical nanomaterilas: the role of particle size, shape and composition. J Appl Toxicol 29:69-78.

Yessine MA, Lafleur M, Meier C, Petereit HU, Leroux JC. 2003. Characterization of the membrane-destabilization properties of different $\mathrm{pH}$-sensitive methacrylic acid copolymers. Biochim Biophys Acta 1613:28-38.

Zhang SB, Xu YM, Wang B, Qiao WH, Liu DL, Li ZS. 2004. Cationic compounds used in lipoplexes and polyplexes for gene delivery. J Control Release 100:165-180. 


\section{Figure captions:}

Figure 1. Cell viability measured by the MTT (a-c) and NRU (d,e) assays, and cytotoxicity expressed by LDH release (f,g) on $3 \mathrm{~T} 3(\mathrm{a}, \mathrm{b}, \mathrm{d}, \mathrm{f})$ and HeLa $(\mathrm{c}, \mathrm{e}, \mathrm{g})$ cell lines. The cells were exposed to increasing concentrations of the surfactants only (a) or of the NV formulations (b-g), ranging from 0.5 to $100 \mu \mathrm{M}$. Results of MTT and NRU assays are given as a percentage of untreated control cells, whereas the cytotoxicity by LDH release was calculated in relation to the positive control set as $100 \% \mathrm{LDH}$ release. The discontinuous straight line in each graph corresponds to untreated control cells set as 100\% cell viability (MTT and NRU) or to positive control cells set as $100 \%$ cell death $(\mathrm{LDH})$. Results are expressed as mean \pm SEM of three independent experiments, performed in triplicate. The data on 3T3 cells for the NVs containing the surfactants are reprinted and adapted from Nogueira et al. 2013, with permission from Elsevier.

Figure 2. Effect of various cationic NVs on apoptosis of $3 \mathrm{~T} 3$ cells determined by fluorescence microscopy after AO and BE staining. (a) Per cent of viable, apoptotic and necrotic cells after 24 $\mathrm{h}$ treatment with the $\mathrm{IC}_{50}$ concentrations (calculated by MTT assay) of each NV formulation. Fluorescent micrographs of (b) untreated control cells, (c) DMPC:MKM, (d) DMPC:CHOL:MKM and (e) DMPC:PKM. Legends: ( ) typical live nuclei, ( $\boldsymbol{\nabla}$ ) chromatin condensation (early apoptosis), ( $\mathbf{\Delta})$ blebbing and nuclear margination (early to moderate apoptosis), $(*)$ necrosis, $(* *)$ late apoptosis. Scale bar: $50 \mu \mathrm{m}$.

Figure 3. Cell-cycle analysis of $3 \mathrm{~T} 3$ cells following $24 \mathrm{~h}$ treatment with $\mathrm{IC}_{20}$ and $\mathrm{IC}_{50}$ concentrations of each NV formulation. NVs containing (a) MKM, (b) PKM and (c) MLM. Results are expressed as mean \pm SEM of three independent experiments, performed in duplicate. Statistical analyses were performed using ANOVA followed by Dunnett's multiple comparison test. $* \mathrm{p}<0.05, * * \mathrm{p}<0.005$ denote significant differences.

Figure 4. DNA damage in $3 \mathrm{~T} 3$ cells determined by a comet assay. The cells were treated for 24 $\mathrm{h}$ with the $\mathrm{IC}_{10}, \mathrm{IC}_{20}$ and $\mathrm{IC}_{30}$ concentrations (calculated by MTT assay) of each NV formulation. Fluorescent micrographs of (a) untreated control cells, (b) cells treated with $400 \mu \mathrm{M}$ of MMS (positive control) and (c) cells treated with $\mathrm{IC}_{20}$ of DMPC:CHOL:PKM. Scale bar: $50 \mu \mathrm{m}$. (d) \% Tail DNA. Values shown are the mean of 50 randomly selected comet images of each sample \pm SEM. Statistical analyses were performed using ANOVA followed by Dunnett's multiple comparison test. $* \mathrm{p}<0.005$ denotes significant differences. 
Figure 5. Quantitative analysis of MDA concentrations after exposure of $3 \mathrm{~T} 3$ cells for $24 \mathrm{~h}$ to the $\mathrm{IC}_{50}$ concentrations of each $\mathrm{NV}$ formulation. MDA is a marker of lipid peroxidation and, thus, of cellular oxidative stress. Results are expressed as mean \pm SEM of three independent experiments, performed in duplicate. Statistical analyses were performed using ANOVA followed by Dunnett's multiple comparison test. * $\mathrm{p}<0.05$, ** $\mathrm{p}<0.005$ denote significant differences.

Figure 6. Blood compatibility of NVs. (a) Percentage of hemolysis caused by NVs after $1 \mathrm{~h}$ of incubation with rat erythrocytes. Each value represents the mean \pm SEM of three experiments. Agglutination of rat erythrocytes observed by phase microscopy after $1 \mathrm{~h}$ of incubation with 100 $\mu \mathrm{M}$ of each NV formulation: (b) control, (c) DMPC:MKM, (d) DMPC:CHOL:MKM, (e) DMPC:PKM, (f) DMPC:CHOL:PKM, (g) DMPC:MLM, (h) DMPC:CHOL:MLM. Scale bar: $100 \mu \mathrm{m}$. Plasma protein adsorption assessed by SDS-PAGE: (i) protein present in the supernatant and (j) protein adsorbed to the NVs after incubation of $10 \%$ plasma with $100 \mu \mathrm{M}$ of each $\mathrm{NV}$ formulation for $1 \mathrm{~h}$ at $37^{\circ} \mathrm{C}$. 1 = DMPC:PKM, $2=$ DMPC:CHOL:PKM, $3=$ DMPC:MKM, 4 = DMPC:CHOL:MKM, 5 = DMPC:MLM, 6 = DMPC:CHOL:MLM, C = control 10\% plasma, $\mathrm{i}$ and $\mathrm{ii}=$ wash fluids from DMPC:PKM and DMPC:MKM samples, respectively.

Figure 7. (A) Localization of NR-NVs (DMPC:MKM) by HeLa cells after $2 \mathrm{~h}$ and $24 \mathrm{~h}$ of incubation at $37^{\circ} \mathrm{C}$. Cell uptake is visualized using fluorescence microscopy. (B) Fluorescence microscopy images of HeLa cells showing the subcellular distribution of calcein fluorescence. The cells were treated with $1 \mathrm{mg} / \mathrm{ml}$ calcein (control), and both $1 \mathrm{mg} / \mathrm{ml}$ calcein and $50 \mu \mathrm{M}$ of each NV formulation. Images were acquired at $3 \mathrm{~h}$ after $1 \mathrm{~h}$ of uptake. Scale bar: $50 \mu \mathrm{m}$. (C) Quantitative fluorescence analysis of images like those in ' $A$ ' and (D) of images like those in ' $B$ '. The results represent the mean of values determined for $\sim 20$ cells \pm SEM. See the Materials and Methods section for details of the analysis performed. Statistical analyses were performed using Student's $t$ test $\left({ }^{++} \mathrm{p}<0.005\right)$ or ANOVA followed by Dunnett's multiple comparison test $(* \mathrm{p}<0.05$ and $* * \mathrm{p}<0.005)$. 


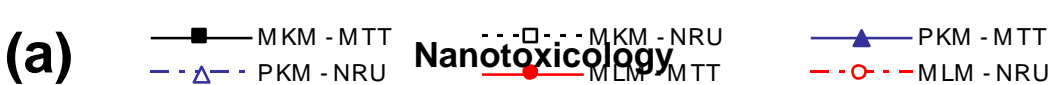

$47 \AA$

48 @

49 ब

50 工

51

52 ב

$53 . \overline{0}$

$54 \stackrel{\times}{\circ}$

55 운

56 ठे

57

58

59

60

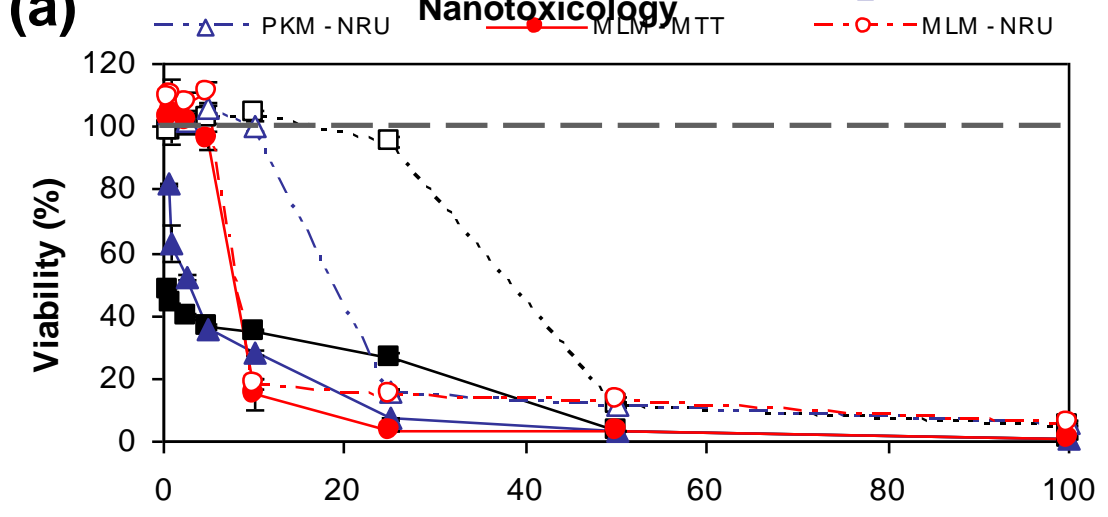

\section{Concentration $\mu \mathrm{M}$}

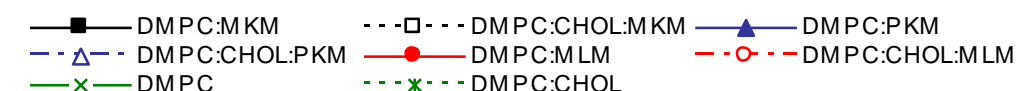
$\triangle-D M P C$
$-x-D M P C$

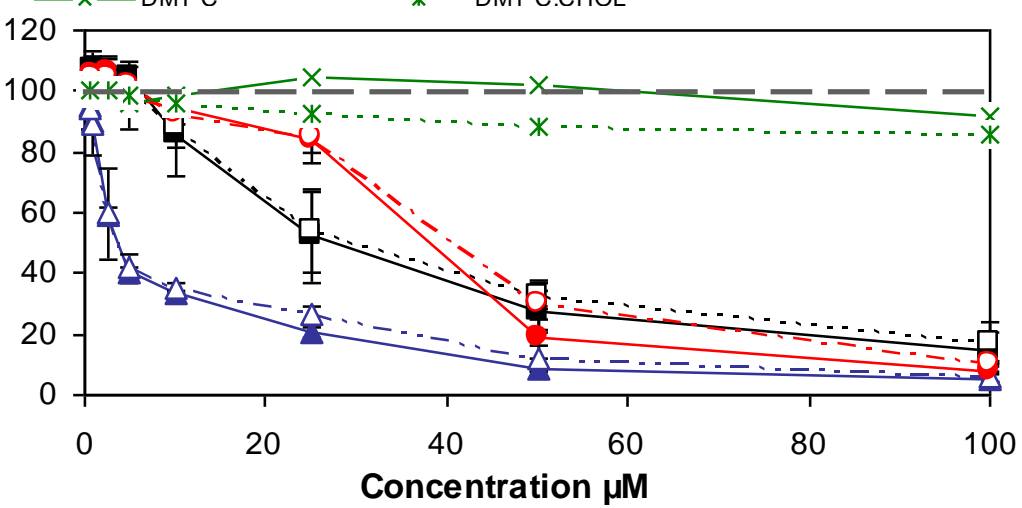

Concentration $\mu \mathrm{M}$

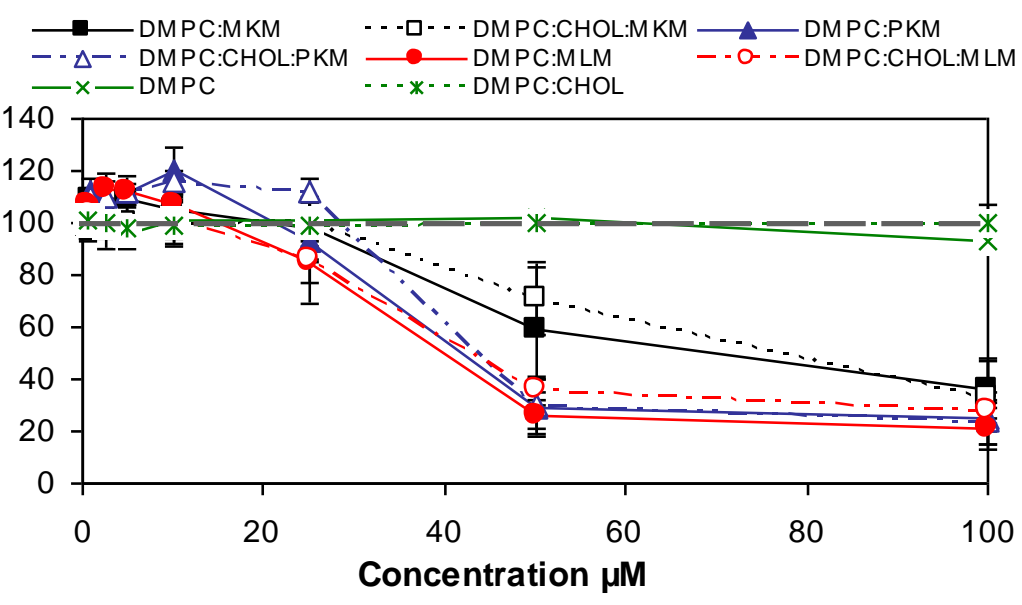

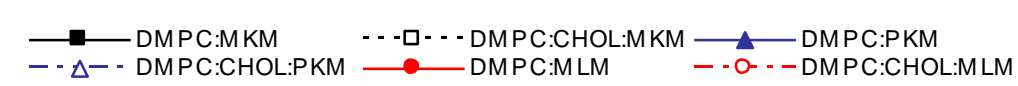
$120 \times-D M P C \quad \cdots *-\cdot D M P C: C H O L$

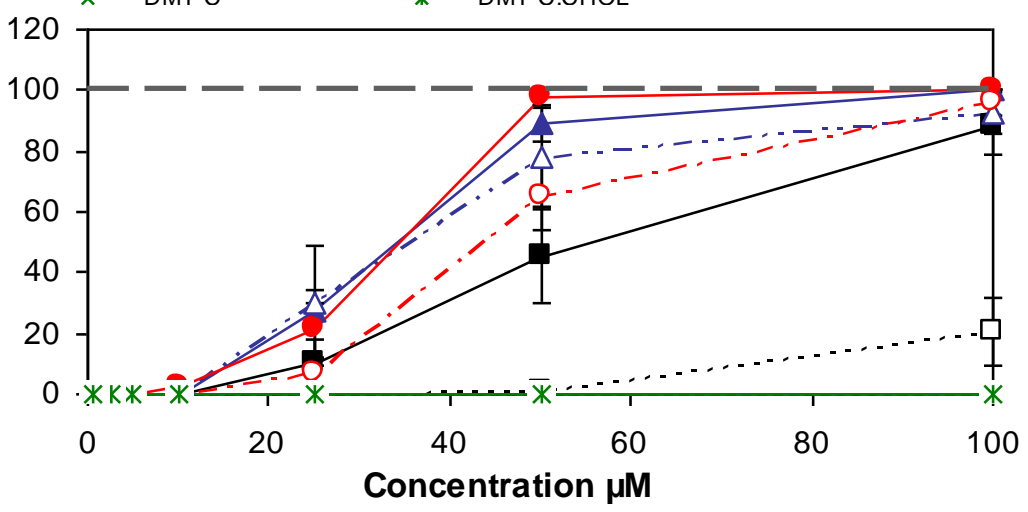

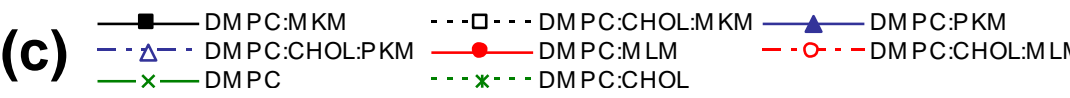

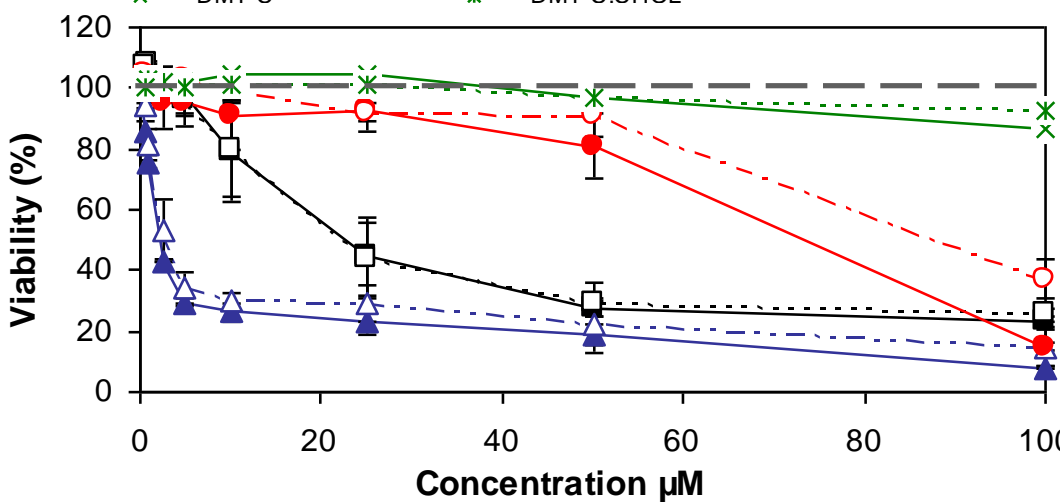

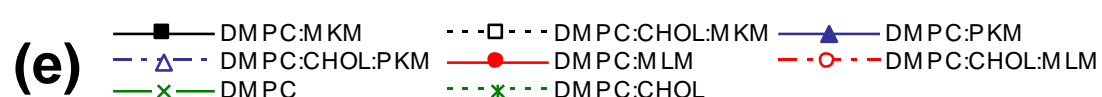

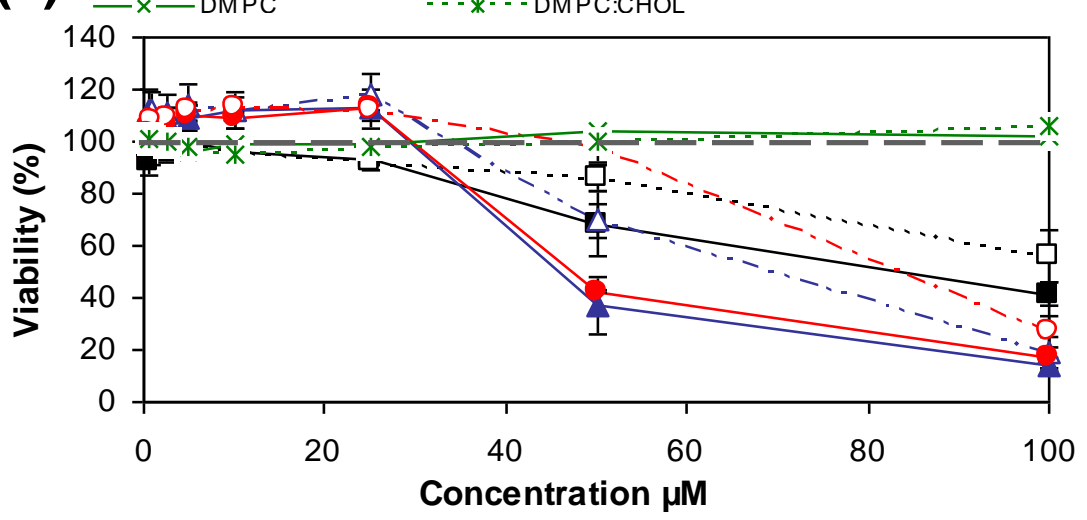

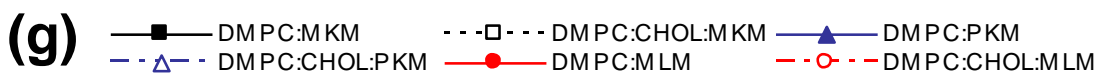
$\overbrace{120} \times$-DMPC

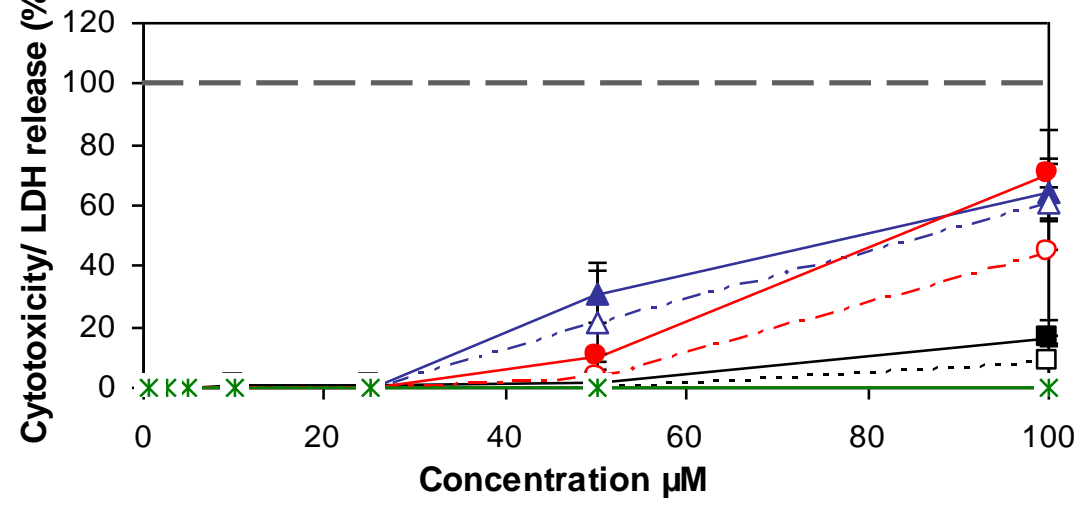

URL: http://mc.manuscriptcentral.com/tnan 


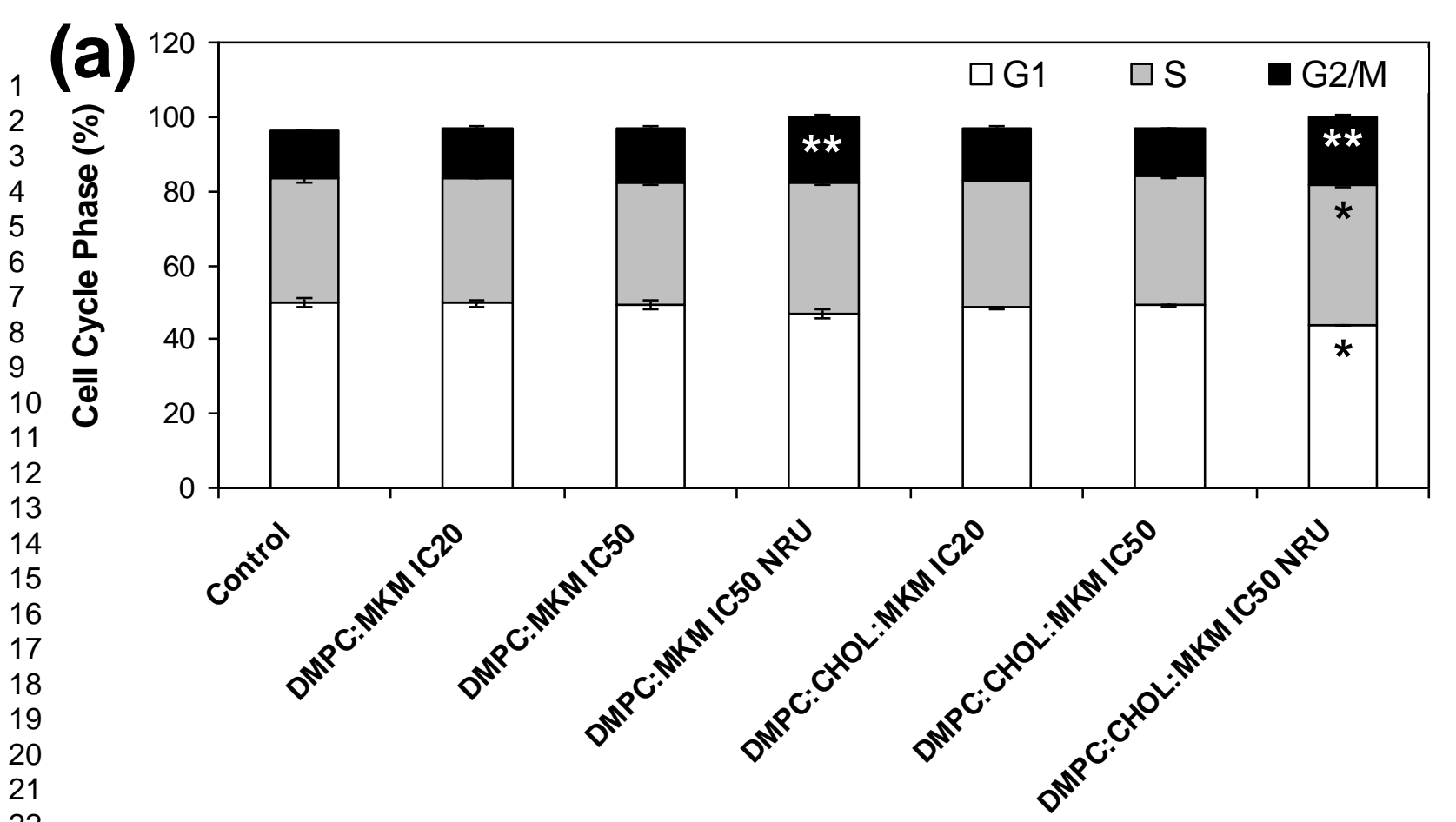

22

(b)
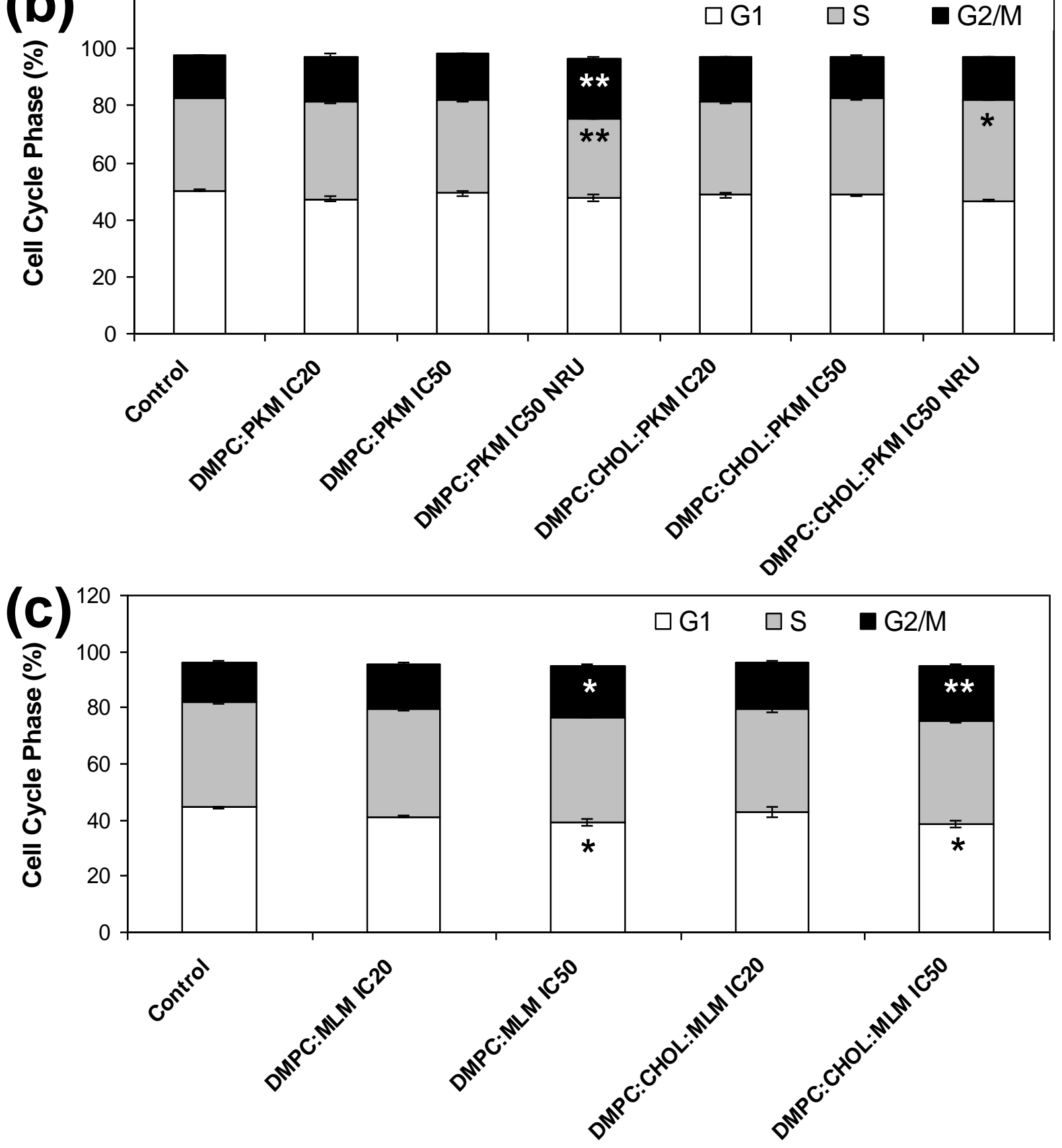


\section{Page 43 of 55}

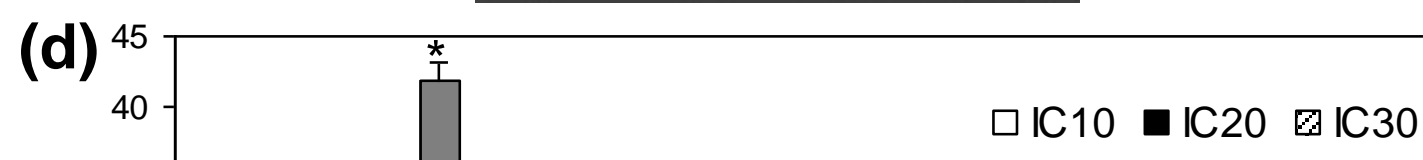


Nanotoxicology

Page 44 of 55

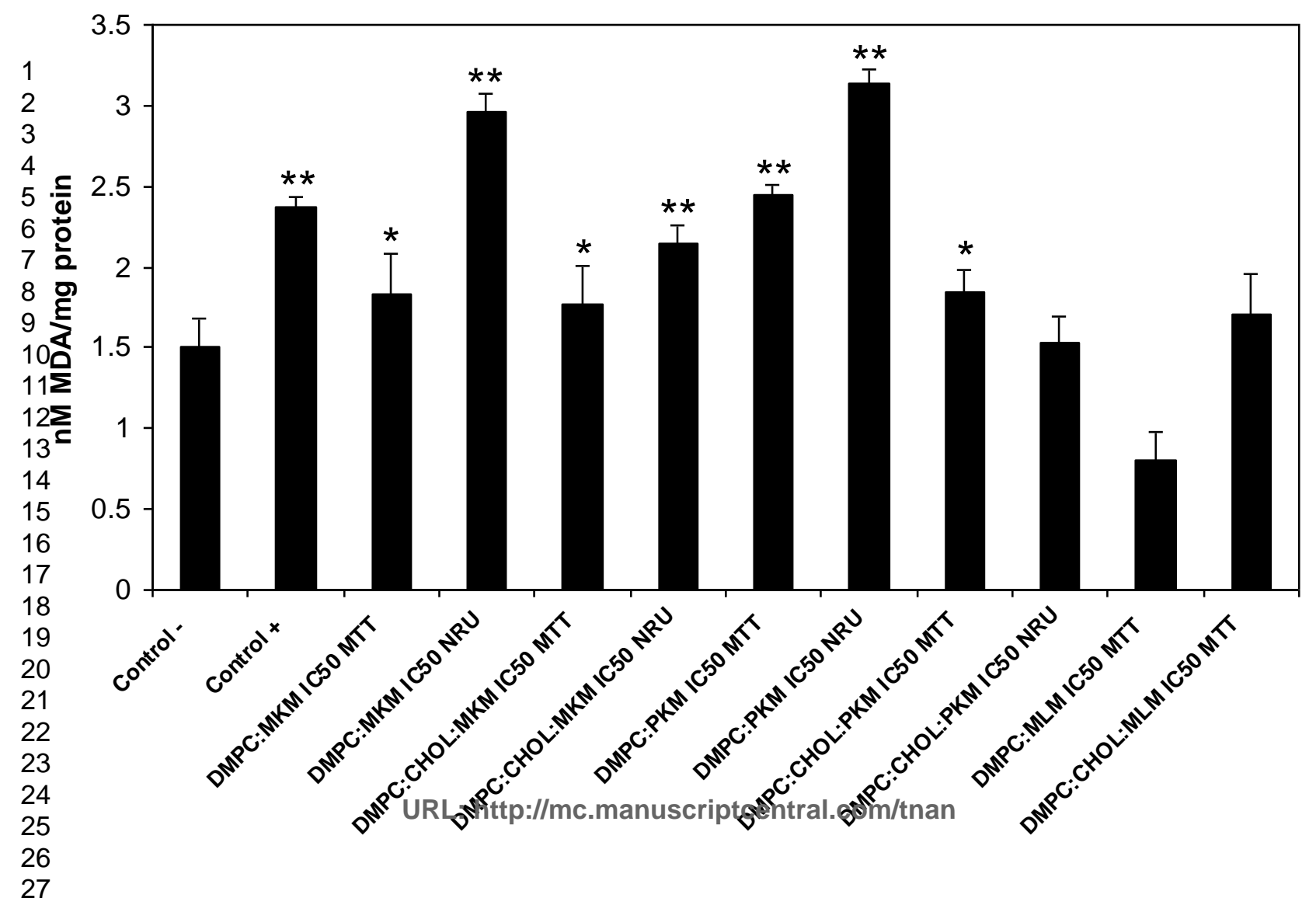




\section{Page 45 of 55}

(a) 90 Nanotoxicology
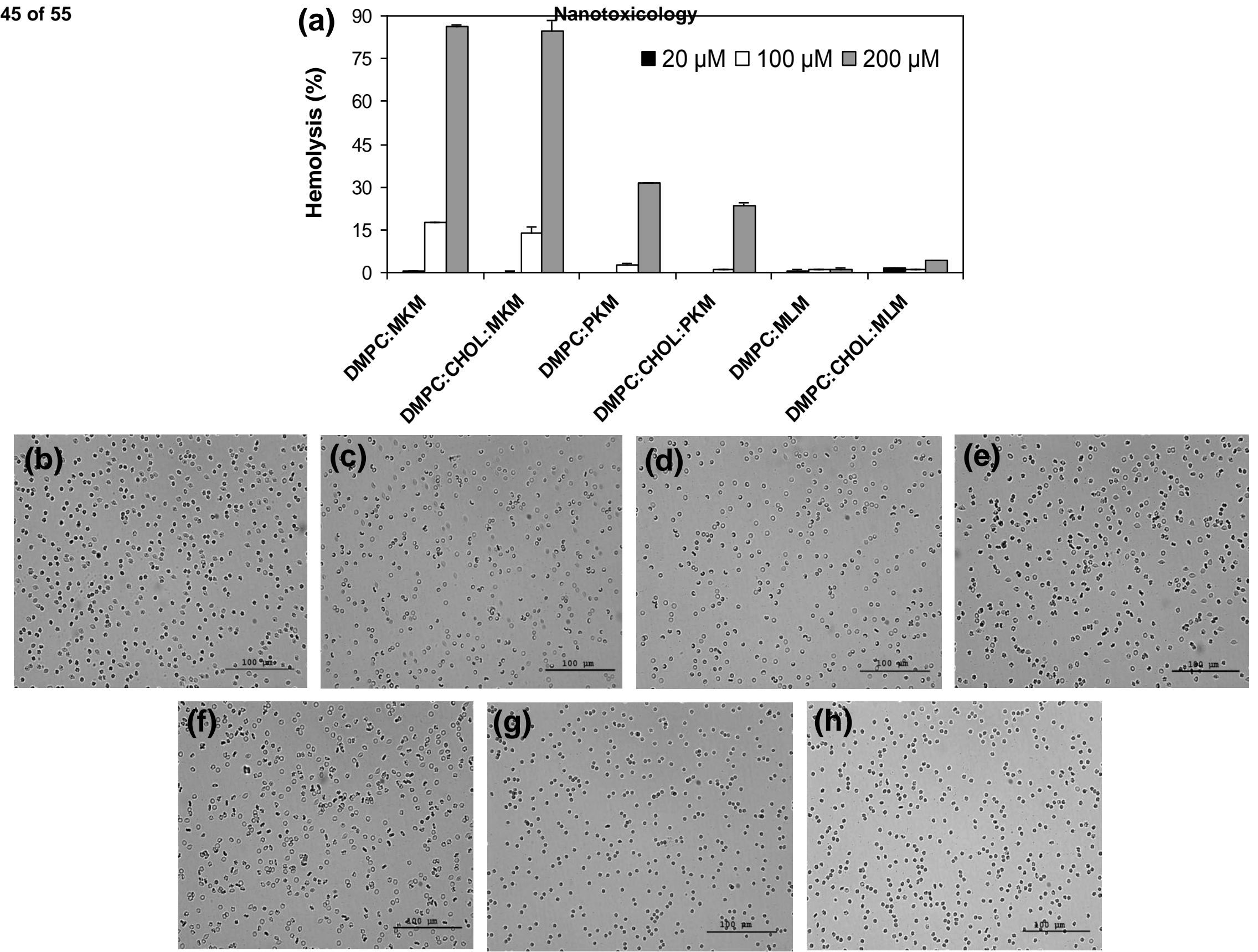

(h)

(i)

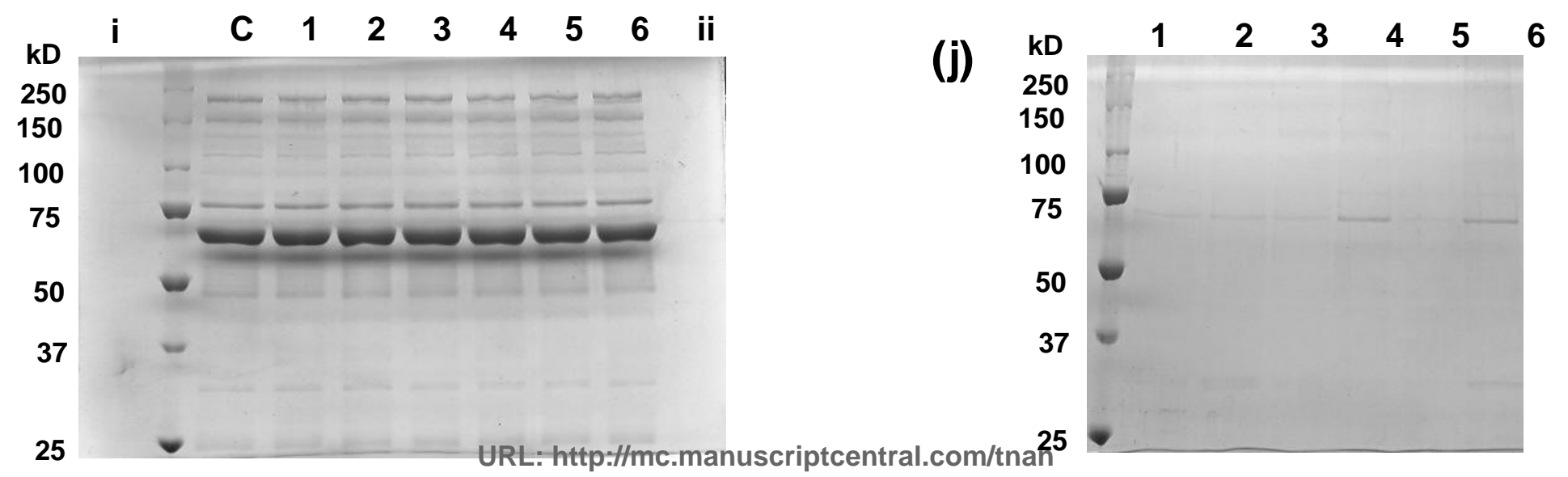



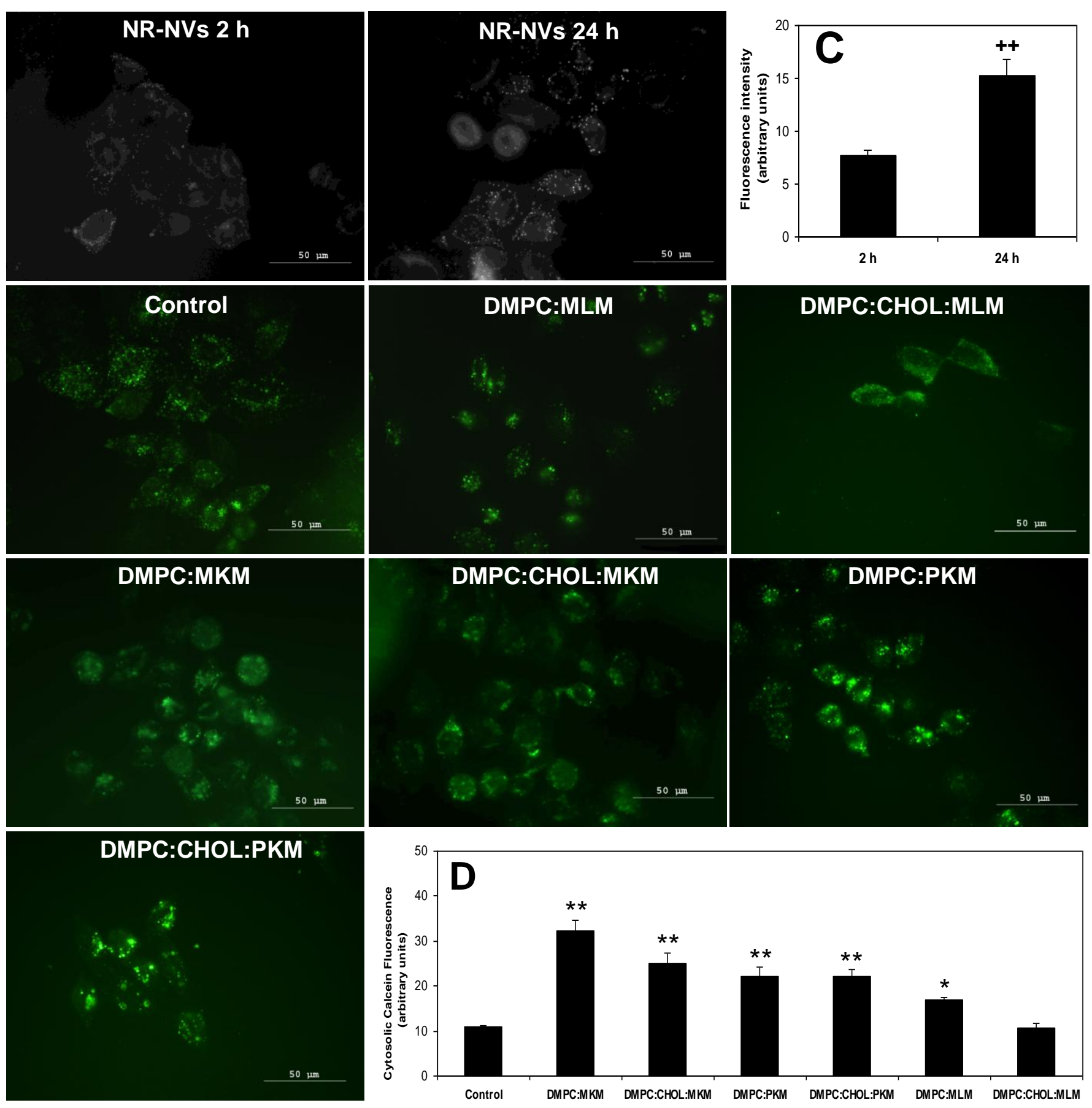

URL: http://mc.manuscriptcentral.com/tnan 
1

2

3

4

5

6

7

8

9

10

11

12

13

14

15

16

17

18

19

20

21

22

23

24

25

26

27

28

29

30

31

32

33

34

35

36

37

38

39

40

41

42

43

44

45

46

47

48

49

50

51

52

53

54

55

56

57

58

59

60

Table 1. Scheme of the nanovesicles' composition.

\begin{tabular}{lccc}
\hline & \multicolumn{3}{c}{ Molar composition (\%) } \\
\hline Nanovesicles & DMPC & $\begin{array}{c}\text { COLESTEROL } \\
\text { (CHOL) }\end{array}$ & $\begin{array}{c}\text { Surfactant } \\
\text { (MKM, PKM o MLM) }\end{array}$ \\
\hline DMPC:surfactant & 80 & - & 20 \\
DMPC:CHOL:surfactant & 56 & 24 & 20 \\
\hline
\end{tabular}


Table 2. Characterization properties of the cationic nanovesicles. Values are reported as mean of three independent experiments \pm SEM.

\begin{tabular}{|c|c|c|c|c|c|c|}
\hline & $\begin{array}{c}\text { DMPC:MKM } \\
(80: 20)\end{array}$ & $\begin{array}{c}\text { DMPC:CHOL:MKM } \\
(56: 24: 20)\end{array}$ & $\begin{array}{c}\text { DMPC:PKM } \\
(80: 20)\end{array}$ & $\begin{array}{c}\text { DMPC:CHOL:PKM } \\
(56: 24: 20)\end{array}$ & $\begin{array}{c}\text { DMPC:MLM } \\
(80: 20)\end{array}$ & $\begin{array}{c}\text { DMPC:CHOL:MLM } \\
(56: 24: 20)\end{array}$ \\
\hline \multicolumn{7}{|c|}{ Size $(\mathrm{nm}) \pm$ SEM } \\
\hline $\mathrm{t}=0 \mathrm{~h}$ water $^{\mathrm{a}}$ & $94.16 \pm 2.05$ & $107.33 \pm 0.94$ & $253.07 \pm 26.05$ & $184.77 \pm 6.64$ & $174.40 \pm 7.16$ & $127.50 \pm 1.96$ \\
\hline $\mathrm{t}=0 \mathrm{~h}$ DMEM $5 \% \mathrm{FBS}^{\mathrm{a}}$ & $94.42 \pm 6.50$ & $159.77 \pm 5.71$ & $229.37 \pm 12.64$ & $197.73 \pm 6.57$ & $229.63 \pm 16.33$ & $170.27 \pm 9.49$ \\
\hline $\mathrm{t}=24 \mathrm{~h}_{\text {water }}^{\mathrm{b}}$ & $89.39 \pm 3.42$ & $82.59 \pm 5.58$ & $\begin{array}{l}355.6 \pm 31.49 / \\
68.71 \pm 7.44^{\mathrm{d}}\end{array}$ & $\begin{array}{c}368.47 \pm 19.56 / \\
77.94 \pm 4.26^{\mathrm{d}}\end{array}$ & $189.53 \pm 5.38$ & $119.57 \pm 4.16$ \\
\hline $\mathrm{t}=24 \mathrm{~h}$ DMEM 5\% FBS ${ }^{\mathrm{a}, \mathrm{b}}$ & $\begin{array}{c}1781.67 \pm 45.72 / \\
110.3 \pm 5.17^{\mathrm{d}}\end{array}$ & $\begin{array}{l}2028.67 \pm 21.23 / \\
154.33 \pm 11.95^{\mathrm{d}}\end{array}$ & $\begin{array}{c}1059.50 \pm 10.61 / \\
118.93 \pm 2.09^{\mathrm{d}}\end{array}$ & $\begin{array}{c}1488 \pm 19.59 / \\
125.67 \pm 11.94^{\mathrm{d}}\end{array}$ & $193.47 \pm 7.75$ & $151.77 \pm 4.44$ \\
\hline $\mathrm{t}=1$ week water ${ }^{\mathrm{c}}$ & $78.41 \pm 4.76$ & $102.86 \pm 4.19$ & $277.9 \pm 22.16$ & $\begin{array}{c}349.23 \pm 18.45 / \\
78.64 \pm 4.10^{\mathrm{d}}\end{array}$ & $173.27 \pm 8.19$ & $130.70 \pm 3.20$ \\
\hline \multicolumn{7}{|c|}{$P D I \pm S E M$} \\
\hline $\mathrm{t}=0 \mathrm{~h}$ water $^{\mathrm{a}}$ & $0.231 \pm 0.004$ & $0.278 \pm 0.019$ & $0.427 \pm 0.017$ & $0.331 \pm 0.020$ & $0.394 \pm 0.003$ & $0.256 \pm 0.006$ \\
\hline $\mathrm{t}=0 \mathrm{~h}$ DMEM 5\% FBS $^{\mathrm{a}}$ & $0.385 \pm 0.015$ & $0.236 \pm 0.001$ & $0.522 \pm 0.001$ & $0.288 \pm 0.001$ & $0.445 \pm 0.007$ & $0.319 \pm 0.029$ \\
\hline $\mathrm{t}=24 \mathrm{~h}$ water $^{\mathrm{b}}$ & $0.371 \pm 0.025$ & $0.378 \pm 0.024$ & $0.508 \pm 0.003$ & $0.523 \pm 0.044$ & $0.399 \pm 0.003$ & $0.239 \pm 0.005$ \\
\hline $\mathrm{t}=24 \mathrm{~h}$ DMEM 5\% FBS ${ }^{\mathrm{a}, \mathrm{b}}$ & $0.903 \pm 0.075$ & $1.00 \pm 0.000$ & $0.605 \pm 0.002$ & $0.973 \pm 0.027$ & $0.294 \pm 0.001$ & $0.352 \pm 0.007$ \\
\hline $\mathrm{t}=1$ week water ${ }^{\mathrm{c}}$ & $0.323 \pm 0.024$ & $0.372 \pm 0.025$ & $0.598 \pm 0.040$ & $0.629 \pm 0.011$ & $0.363 \pm 0.024$ & $0.241 \pm 0.002$ \\
\hline \multicolumn{7}{|c|}{ Zeta potential $(\mathrm{mV}) \pm S E M$} \\
\hline $\mathrm{t}=0 \mathrm{~h}$ water $^{\mathrm{a}}$ & $42.7 \pm 0.90$ & $41.2 \pm 1.66$ & $52.8 \pm 1.15$ & $55.17 \pm 0.67$ & $78.7 \pm 2.56$ & $44.9 \pm 0.40$ \\
\hline $\mathrm{t}=0 \mathrm{~h}$ DMEM 5\% FBS ${ }^{\mathrm{a}}$ & $1.23 \pm 1.64$ & $-3.13 \pm 0.81$ & $6.78 \pm 0.94$ & $0.86 \pm 0.11$ & $13.00 \pm 0.49$ & $8.61 \pm 0.16$ \\
\hline $\mathrm{t}=1$ week water ${ }^{\mathrm{c}}$ & $46.67 \pm 1.13$ & $53.97 \pm 1.85$ & $52.23 \pm 0.87$ & $32.15 \pm 2.90$ & $52.53 \pm 0.79$ & $45.90 \pm 1.00$ \\
\hline \multicolumn{7}{|c|}{$\%$ incorporation of surfactant into $N V S \pm S E M^{a}$} \\
\hline & $88.56 \pm 0.009$ & $75.96 \pm 0.054$ & $99.10 \pm 0.007$ & $98.96 \pm 0.006$ & $90.85 \pm 0.053$ & $79.05 \pm 0.038$ \\
\hline \multicolumn{7}{|c|}{ TEM diameter $(\mathrm{nm})^{e}$} \\
\hline $\mathrm{t}=0 \mathrm{~h}$ water & $20-50$ & $20-50$ & $20-50 / 100-150$ & $20-50 / 100-150$ & $150-200$ & $90-110$ \\
\hline TEM images $^{a, f}$ & & & & & & \\
\hline
\end{tabular}

\footnotetext{
${ }^{\mathrm{a}}$ Nogueira et al. $2013 ;{ }^{\mathrm{b}}$ Incubated under cell culture conditions: $37^{\circ} \mathrm{C}, 5 \% \mathrm{CO}_{2} ;{ }^{\mathrm{c}} 4^{\mathrm{o}} \mathrm{C} ;{ }^{\mathrm{d}}$ predominanting size is indicated first; ${ }^{\mathrm{e}}$ predominant population; ${ }^{\mathrm{f}}$ Scale bars $=100 \mathrm{~nm}$;
} 


\section{Page 49 of 55}

Nanotoxicology

1
2
3
4
5
6
7
8
9
10
11
12
13
14
15
16
17
18
19
20
21
22
23
24
25
26
27
28
29
30
31
32
33
34
35
36
37
38
39
40 
Table 3. Summary of the structure-activity relationship of the cellular events in response to NVs.

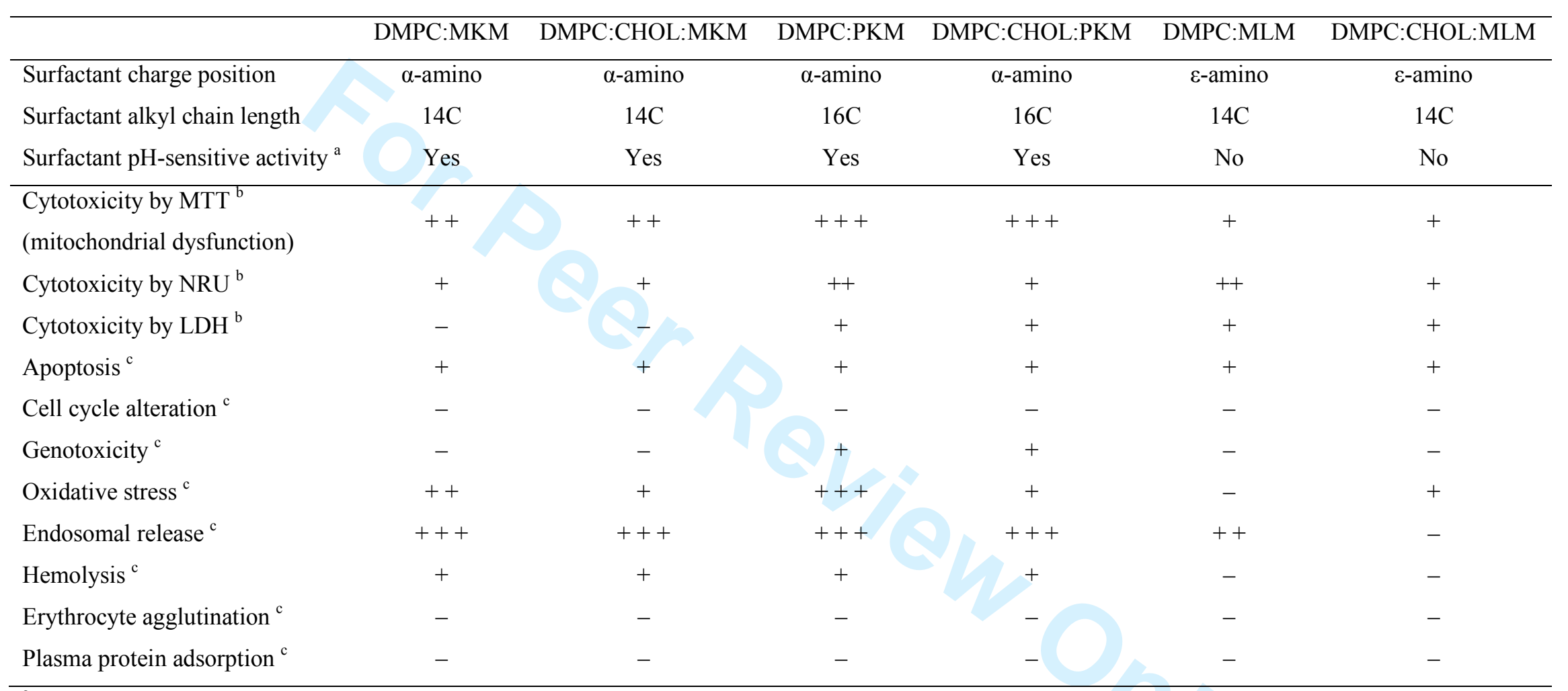

${ }^{a}$ As previously reported (Nogueira et al. 2012a, 2012b).

The number of plus signs is a semiquantitative measure according to which: ${ }^{\mathrm{b}}+$ refers to low $\left(50<\mathrm{IC}_{50}<100 \mu \mathrm{M}\right),++$ to medium $\left(10<\mathrm{IC} 50^{<}<50 \mu \mathrm{M}\right)$ and +++ to high cytotoxicity $\left(\mathrm{IC}_{50}<10 \mu \mathrm{M}\right)$. Negligible cytotoxicity was considered when the $\mathrm{IC}_{50}$ was higher than $100 \mu \mathrm{M}(-) ;{ }^{\mathrm{c}}+$ refers to $5-33 \%$ value higher than the response of untreated control cells, ++ to $33-66 \%$, and +++ to $>66 \%$. A $<5 \%$ value change was considered as equivocal effect $(-)$. 
2

$08 / 03 / 13$

Rightslink Printable License

ELSEVIER LICENSE

TERMS AND CONDITIONS

Mar 08, 2013

This is a License Agreement between Pilar Vinardell ("You") and Elsevier ("Elsevier") provided by Copyright Clearance Center ("CCC"). The license consists of your order details, the terms and conditions provided by Elsevier, and the payment terms and conditions.

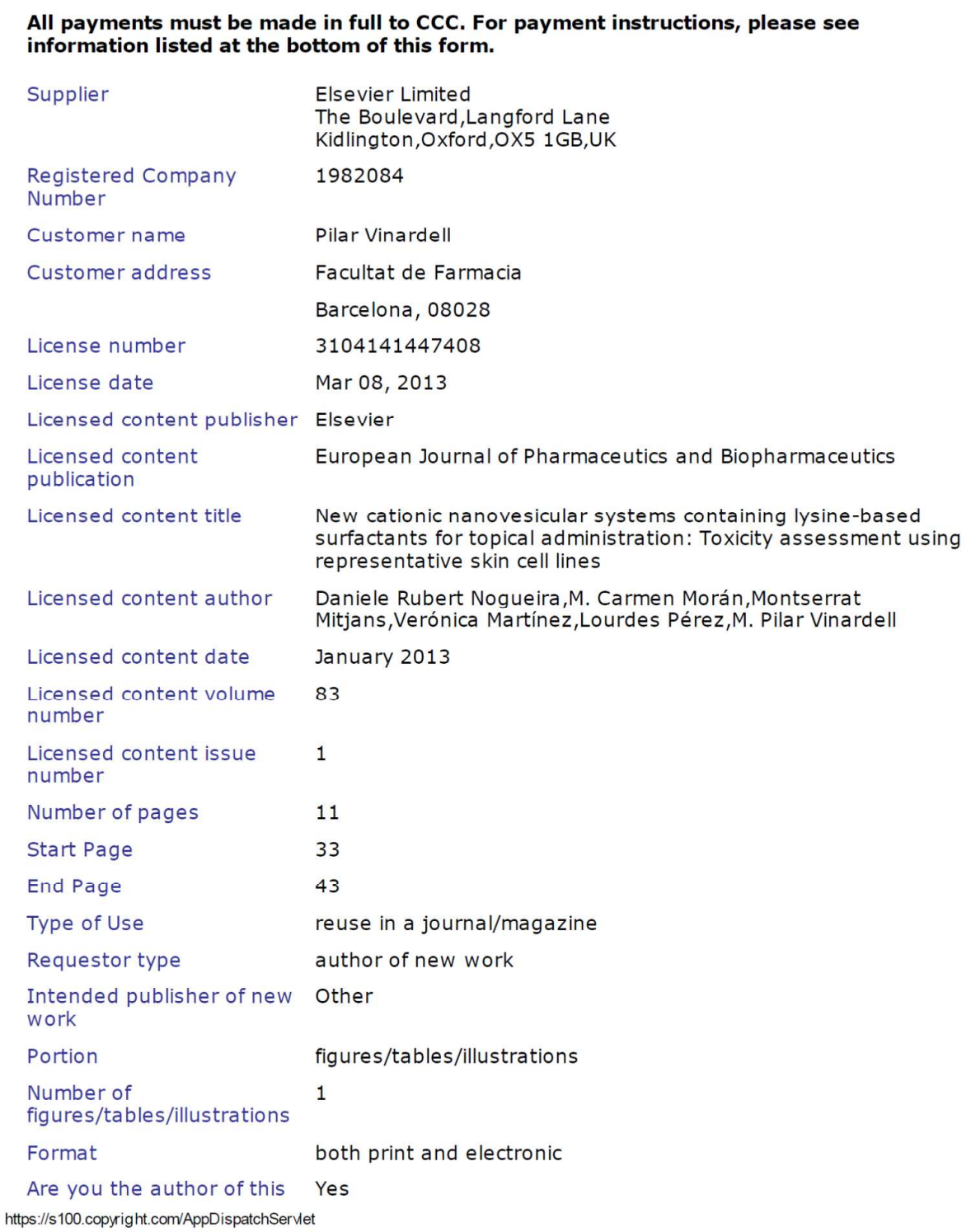




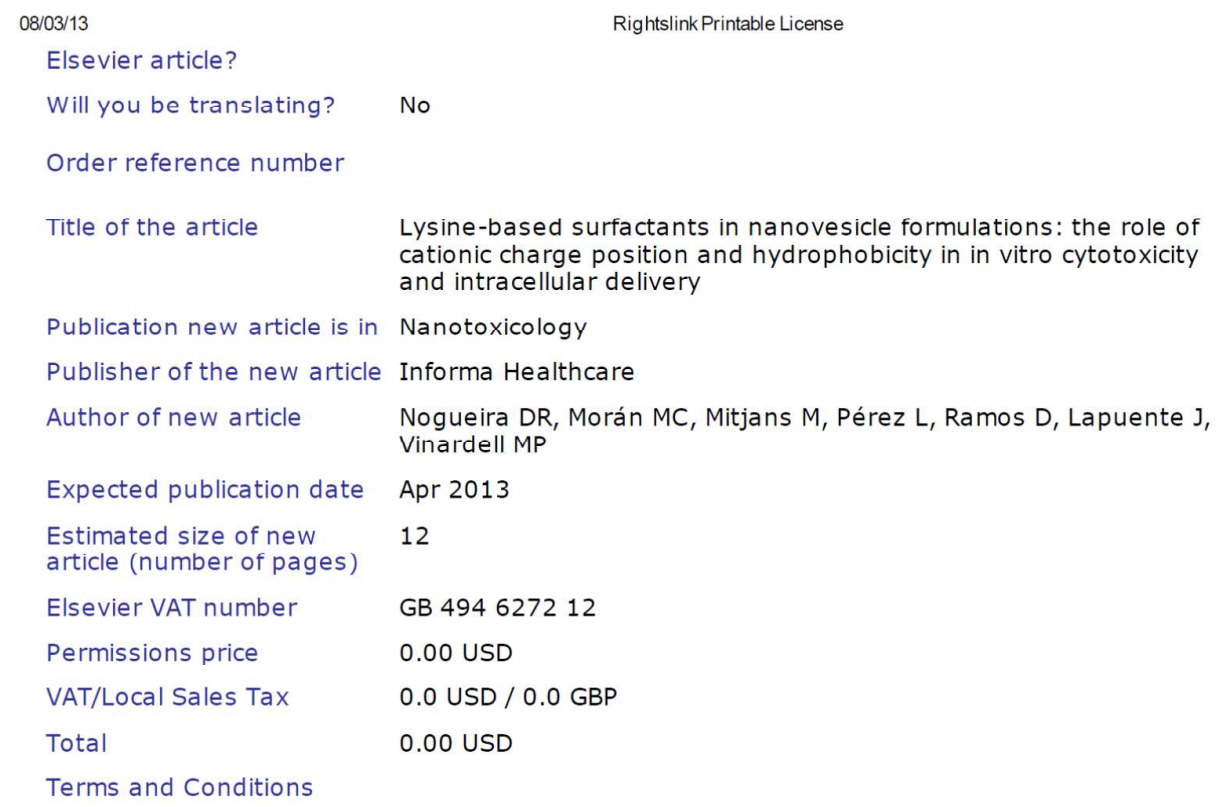

\section{INTRODUCTION}

1. The publisher for this copyrighted material is Elsevier. By clicking "accept" in connection with completing this licensing transaction, you agree that the following terms and conditions apply to this transaction (along with the Billing and Payment terms and conditions established by Copyright Clearance Center, Inc. ("CCC"), at the time that you opened your Rightslink account and that are available at any time at http $/ /$ mvaccount.copvright.com).

\section{GENERAL TERMS}

2. Elsevier hereby grants you permission to reproduce the aforementioned material subject to the terms and conditions indicated.

3. Acknowledgement: If any part of the material to be used (for example, figures) has appeared in our publication with credit or acknowledgement to another source, permission must also be sought from that source. If such permission is not obtained then that material may not be included in your publication/copies. Suitable acknowledgement to the source must be made, either as a footnote or in a reference list at the end of your publication, as follows:

"Reprinted from Publication title, Vol/edition number, Author(s), Title of article / title of chapter, Pages No., Copyright (Year), with permission from Elsevier [OR APPLICABLE SOCIETY COPYRIGHT OWNER]." Also Lancet special credit - "Reprinted from The Lancet, Vol number, Author(s), Title of article, Pages No., Copyright (Year), with permission from Flsevier."

4. Reproduction of this material is confined to the purpose and/or media for which permission is hereby given.

5. Altering/Modifying Material: Not Permitted. However figures and illustrations may be altered/adapted minimally to serve your work. Any other abbreviations, additions, deletions and/or any other alterations shall be made only with prior written authorization of Elsevier Ltd. (Please

https://s100.copyright.com/AppDispatchServet 
contact Elsevier at permissions@elsevier.com)

6. If the permission fee for the requested use of our material is waived in this instance, please be advised that your future requests for Elsevier materials may attract a fee.

7. Reservation of Rights: Publisher reserves all rights not specifically granted in the combination of (i) the license details provided by you and accepted in the course of this licensing transaction, (ii) these terms and conditions and (iii) CCC's Billing and Payment terms and conditions.

8. License Contingent Upon Payment: While you may exercise the rights licensed immediately upon issuance of the license at the end of the licensing process for the transaction, provided that you have disclosed complete and accurate details of your proposed use, no license is finally effective unless and until full payment is received from you (either by publisher or by $\mathrm{CCC}$ ) as provided in CCC's Billing and Payment terms and conditions. If full payment is not received on a timely basis, then any license preliminarily granted shall be deemed automatically revoked and shall be void as if never granted. Further, in the event that you breach any of these terms and conditions or any of CCC's Billing and Payment terms and conditions, the license is automatically revoked and shall be void as if never granted. Use of materials as described in a revoked license, as well as any use of the materials beyond the scope of an unrevoked license, may constitute copyright infringement and publisher reserves the right to take any and all action to protect its copyright in the materials.

9. Warranties: Publisher makes no representations or warranties with respect to the licensed material.

10. Indemnity: You hereby indemnify and agree to hold harmless publisher and $\mathrm{CCC}$, and their respective officers, directors, employees and agents, from and against any and all claims arising out of your use of the licensed material other than as specifically authorized pursuant to this license.

11. No Transfer of License: This license is personal to you and may not be sublicensed, assigned, or transferred by you to any other person without publisher's written permission.

12. No Amendment Except in Writing: This license may not be amended except in a writing signed by both parties (or, in the case of publisher, by CCC on publisher's behalf).

13. Objection to Contrary Terms: Publisher hereby objects to any terms contained in any purchase order, acknowledgment, check endorsement or other writing prepared by you, which terms are inconsistent with these terms and conditions or CCC's Billing and Payment terms and conditions. These terms and conditions, together with CCC's Billing and Payment terms and conditions (which are incorporated herein), comprise the entire agreement between you and publisher (and CCC) concerning this licensing transaction. In the event of any conflict between your obligations established by these terms and conditions and those established by CCC's Billing and Payment terms and conditions, these terms and conditions shall control.

14. Revocation: Elsevier or Copyright Clearance Center may deny the permissions described in this License at their sole discretion, for any reason or no reason, with a full refund payable to you. Notice of such denial will be made using the contact information provided by you. Failure to receive such notice will not alter or invalidate the denial. In no event will Flsevier or Copyright Clearance Center be responsible or liable for any costs, expenses or damage incurred by you as a result of a denial of your permission request, other than a refund of the amount(s) paid by you to Elsevier and/or Copyright Clearance Center for denied permissions. 


\section{LIMITED LICENSE}

The following terms and conditions apply only to specific license types:

15. Translation: This permission is granted for non-exclusive world English rights only unless your license was granted for translation rights. If you licensed translation rights you may only translate this content into the languages you requested. A professional translator must perform all translations and reproduce the content word for word preserving the integrity of the article. If this license is to re-use 1 or 2 figures then permission is granted for non-exclusive world rights in all languages.

16. Website: The following terms and conditions apply to electronic reserve and author websites: Electronic reserve: If licensed material is to be posted to website, the web site is to be password-protected and made available only to bona fide students registered on a relevant course if:

This license was made in connection with a course,

This permission is granted for 1 year only. You may obtain a license for future website posting, All content posted to the web site must maintain the copyright information line on the bottom of each image,

A hyper-text must be included to the Homepage of the journal from which you are licensing at http://www.sciencedirect.com/science/journal/xxxxx or the Elsevier homepage for books at http://www.elsevier.com, and

Central Storage: This license does not include permission for a scanned version of the material to be stored in a central repository such as that provided by Heron/XanEdu.

17. Author website for journals with the following additional clauses:

All content posted to the web site must maintain the copyright information line on the bottom of each image, and the permission granted is limited to the personal version of your paper. You are not allowed to download and post the published electronic version of your article (whether PDF or HTML, proof or final version), nor may you scan the printed edition to create an electronic version. A hyper-text must be included to the Homepage of the journal from which you are licensing at http $/ /$ www.sciencedirect.com/science/journal/xxxxx . As part of our normal production process, you will receive an e-mail notice when your article appears on Elsevier's online service ScienceDirect (www.sciencedirect.com). That e-mail will include the article's Digital Object Identifier (DOI). This number provides the electronic link to the published article and should be included in the posting of your personal version. We ask that you wait until you receive this e-mail and have the DOI to do any posting.

Central Storage: This license does not include permission for a scanned version of the material to be stored in a central repository such as that provided by Heron/XanEdu.

18. Author website for books with the following additional clauses:

Authors are permitted to place a brief summary of their work online only.

A hyper-text must be included to the Elsevier homepage at http $/ /$ www.elsevier.com . All content posted to the web site must maintain the copyright information line on the bottom of each image. You are not allowed to download and post the published electronic version of your chapter, nor may you scan the printed edition to create an electronic version.

Central Storage: 'This license does not include permission for a scanned version of the material to 
be stored in a central repository such as that provided by Heron/XanEdu.

19. Website (regular and for author): A hyper-text must be included to the Homepage of the journal from which you are licensing at $\underline{h t p} / / \mathrm{www}$.sciencedirect.com/science/journal/xxxxx. or for books to the Elsevier homepage at http:/www.elsevier.com

20. Thesis/Dissertation: If your license is for use in a thesis/dissertation your thesis may be submitted to your institution in either print or electronic form. Should your thesis be published commercially, please reapply for permission. These requirements include permission for the Library and Archives of Canada to supply single copies, on demand, of the complete thesis and include permission for UMI to supply single copies, on demand, of the complete thesis. Should your thesis be published commercially, please reapply for permission.

\section{Other Conditions:}

v1.6

If you would like to pay for this license now, please remit this license along with your payment made payable to "COPYRIGHT CLEARANCE CENTER" otherwise you will be invoiced within $\mathbf{4 8}$ hours of the license date. Payment should be in the form of a check or money order referencing your account number and this invoice number RLNK500972980. Once you receive your invoice for this order, you may pay your invoice by credit card. Please follow instructions provided at that time.

Make Payment To:

Copyright Clearance Center

Dept 001

P.O. Box 843006

Boston, MA 02284-3006

For suggestions or comments regarding this order, contact RightsLink Customer Support: customercare@copyright.com or +1-877-622-5543 (toll free in the US) or +1-978-6462777.

Gratis licenses (referencing $\$ 0$ in the Total field) are free. Please retain this printable license for your reference. No payment is required. 